\title{
Domestic laundering - environmental audit in Glasgow with emphasis on passive indoor drying and air quality
}

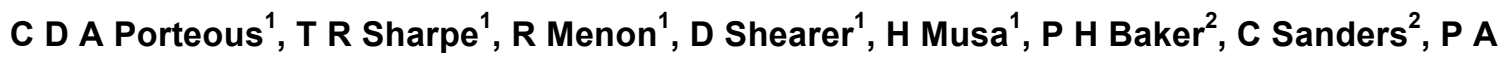 \\ Strachan $^{3}$, N J Kelly ${ }^{3}$ and A Markopoulos ${ }^{3}$
}

1: Mackintosh Environmental Architecture Research Unit (MEARU), Mackintosh School of Architecture, The Glasgow School of Art, 167 Renfrew St, Glasgow G3 6RQ; Tel. +141-353-4657

Principal Investigator: Prof Colin Porteous c.porteous@gsa.ac.uk (corresponding author);

Co-investigators: Dr Tim Sharpe t.sharpe@gsa.ac.uk; Rosalie Menon r.menon@gsa.ac.uk;

Donald Shearer d.shearer@gsa.ac.uk; Senior Research Assistant: Dr Haruna Musa

H.Musa@mmu.ac.uk.

2: Centre for Research on Indoor Climate \& Health $(\mathrm{RICH})$, Glasgow Caledonian University

Co-investigators: Dr Paul Baker Paul.Baker@gcu.ac.uk; Chris Sanders C.H.Sanders@gcu.ac.uk.

3: Energy Systems Research Unit (ESRU), University of Strathclyde

Co-investigators: Dr Paul Strachan paul@esru.strath.ac.uk; Dr Nick Kelly

<nick@esru.strath.ac.uk>; PhD student: Anastasios Markopoulos

<anastasios@esru.strath.ac.uk>. 


\title{
Domestic laundering - environmental audit in Glasgow with emphasis on passive indoor drying and air quality
}

\begin{abstract}
As the UK and Scottish governments aim for zero-carbon housing, with tightly sealed building envelopes becoming paramount, indoor air quality (IAQ) and its implications for health has become a concern. This context relates to the reported findings of a 2008-2011 study, 'Environmental Assessment of Domestic Laundering', concerning the prevalence of passive indoor drying (PID). Assessment of PID impacts, shaped by built and social context including occupants' habits and trends, draws on monitored data from 22 case studies out of a wider survey of 100 dwellings in Glasgow. The smaller group included analysis of air samples, and provided scenarios for enhanced dynamic modelling via laboratory work on moisture buffering. The evidence suggests PID has important implications for energy consumption and IAQ; in the latter case because moisture levels are likely to boost dust mite populations and concentrations of airborne mould spores. Thus findings suggest possible negative impacts on health. Further work concerning VOCs and laundering is also advocated. The paper concludes by recommending amended building standards allied to design guidance for improved practice; these aiming to prevent PID moisture diffusion within habitable rooms by upgrading minimum requirements, and also to require enhanced outdoor drying facilities.
\end{abstract}

Keywords: domestic laundering; dust mites; energy; health; indoor air quality; mould spores 


\section{Introduction}

The overall research aim of the study 'Environmental Assessment of Domestic Laundering' $(E A D L)$ was to investigate the energy use and other potentially detrimental environmental impacts that are attributable to domestic laundering, and to develop recommendations to address and improve both aspects. The part played by laundering appliances in this regard has been addressed elsewhere [1]. This paper concentrates on the impact of passive indoor drying (PID), and to a lesser extent ironing, has on both on indoor air quality (IAQ) and energy efficiency. The research investigated several interactive research strands: humidity, mould risk, PID influences and standards of IAQ using $\mathrm{CO}_{2}$ to indicate 'bad company'; air sampling and analysis of mould spores; moisture buffering potential of certain building materials, involving laboratory analysis; and dynamic computer modelling to determine moisture and energy impacts of PID. These strands connect to potential health issues associated with IAQ and humidity - e.g. asthma (addressed theoretically relative to moisture levels and presence of airborne mould spores). The issue of volatile organic compounds (VOCs) lay outside the remit of EADL.

Social rented housing in Glasgow was used as the main investigatory vehicle for two reasons. Firstly, it targets the greatest need and risk in terms of low income relative to laundering loads, and corresponds with high intensity of occupation over daily and weekly cycles. Secondly, there was good accessibility, with previous involvement by the research team. However, some private sector homes were included, and, despite the dominance of various types and ages of urban Glasgow flats over more suburban forms, the demography and findings are deemed relevant and transferable to all housing sectors and beyond Scotland [1].

This paper confines itself to those aspects of the research objectives that relate primarily to the influences of PID on IAQ and possibilities for mitigation:

(i) To evaluate these influences in varied house types and demography, in terms of the balance between energy efficiency and good air quality, related problems such as condensation risk, and associated health implications.

(ii) To measure and improve knowledge of transient, moisture-related properties of relevant materials, surface finishes, furniture, etc. To also augment (i) by analysis of air samples. 
(iii) To extract performance metrics for the design variables studied, based on scenarios from (i) and material tests in (ii) and to generate a theoretical framework enhancing the capabilities of ESP-r [2] to dynamically model transient moisture transport.

(iv) To influence housing procurement, aiming for improved statutory standards and disseminate a design guide detailing best practice. ${ }^{1}$

The context for EADL was outlined by Porteous [3] who provided a historic review of IAQ and its influence on energy and health. Despite the lengthy build-up of knowledge between Dalton's early $19^{\text {th }} \mathrm{C}$ work on dew-point and mid- $20^{\text {th }} \mathrm{C}$ capability to carry out a full constructional analysis of condensation risk, mould growth continues to be problematic within housing. This is in part due to the drive towards energy efficiency at the apparent expense of IAQ. The review also notes that the $19^{\text {th }} \mathrm{C}$ standard of $1,000 \mathrm{ppm} \mathrm{CO}_{2}$ endures today as a desirable maximum indicator of IAQ, despite significant socio-cultural changes. Similarly, the core method of air sampling and analysis dates from the 1880s [4] and remains a relevant precedent for equivalent data from EADL.

$21^{\text {st }} \mathrm{C}$ research by Shove prior to EADL challenged the likelihood of effective intervention relative to changing human behaviour and lifestyle "outside the field of view" [5]. Shove documented longterm social changes concerning domestic laundering within the topic 'comfort, cleanliness and convenience' $[6 ; 7]-$ e.g. citing scripts "written into ...domestic washing machines and into the co-requisite sociotechnical arrangements (closed windows, machine washable clothing, etc.)". Here, she relies on indirect data from Unilever interviewees, and appears to neglect PID, comparing tumble-drying to external line drying only. Household habits, including those relating to domestic laundering, are also summarised in recent Swedish work [8], using 31 dwellings of German Passivhaus standard. Contemporaneous UK work on patterns of domestic energy consumption argues that multi-disciplinary research is required to interpret and act on highly variable and context-dependent findings [9]. Another Swedish study relates three specific family circumstances to the efficiency and energy consumption of washing and drying, the latter split between machine drying and PID [10]. Work on the health risk associated with Passivhausstandard dwellings in the Netherlands [11] acknowledges PID as problematic and suggests alternative drying methods such as covered outdoor areas or special rooms. 
The overall significance of occupants' traits and habits with respect to IAQ and energy efficiency has been increasingly brought to the fore. Work in Denmark [12] highlights the issue of opening windows and adjusting set points on thermostats in response to perception of warmth and the perceived ambient environment. However, PID does not figure in this appraisal. Similarly, an earlier Danish study investigated IAQ via exposure-response relationships for emissions from building products, but not for portable items introduced through recurring events such as PID [13]. Work on perceived air quality and materiality (organic vs. synthetic building materials) suggests that a fragrance perceived as pleasant will give higher odour acceptability [14]. The latter raises a question as to whether fragrance from detergents and additives would raise or lower odour acceptability. Although such issues have been cited within larger reports [15], PID and its influence on energy efficiency and IAQ remains under-investigated. This is the context that justified EADL, and within it, examination of PID - the reasons for its prevalence and its impacts.

\section{Method}

A survey of 100 households in Glasgow was conducted (S100). These embraced both demographic and architectural variety, with an 'interview-observe-measure' survey process carried out in differing weather over a calendar year. This consisted of a comprehensive questionnaire, subject to observational checking and additional research by the investigator (e.g. relevant architectural information), and measurements of temperature, relative humidity and $\mathrm{CO}_{2}$ (maximum 5,000 ppm) in order to provide a 'snapshot' of found conditions during daytime; and for later comparison with continuous measurements over a 2-week period for a smaller cohort of dwellings from the main set. The three environmental parameters were recorded with an Eltek (Cambridge, UK) GENII Telemetry Transmitter GD-47, and vapour pressure was subsequently computed as a measure of absolute humidity, partly for comparison with $\mathrm{CO}_{2}$ readings.

The questionnaire was devised to capture relevant contextual information together with specific laundering data. Some queries aimed to establish operational reasoning as well as views concerning perceived problems. Objective context included: type of dwelling, number of bedrooms, family make-up, intensity of occupation on weekdays and weekend; basic construction, floor finishes and furnishing; heating means and operation, methods of payments 
and estimated costs; and ventilation means and operation and any visual evidence of mould. Laundering data included: individual appliances for washing, drying and ironing, operational frequency, load settings, detergent types etc. and reasons for use partial use or non-use; use of communal appliances, reasons for this and location; special emphasis on means of drying where when and why for PID, passive outdoor drying (POD), and tumble drying (TD); individual and communal split, and, in the former case, associated heating and ventilating habits, and perceptions of indoor humidity.

Although the scope of EADL did not extend to health outcomes, the methodology aimed to establish presence of indicators that other work has already shown to be relevant to aspects of health (e.g. humidity, dust mite population and asthma). The energy-IAQ balance is delicate, and the data acquisition and subsequent analysis aims to explore the environmental vulnerability of increasingly airtight building envelopes coupled with relatively unstructured control of ventilation. In the sample in Glasgow the extent to which dwellings were insulated and airtight was not compliant with current standards, and airtightness depended mainly on double-glazed windows (not measured, but self-evident relative to age/type of properties). User awareness of ventilation, and the means or lack of its control, was a key issue alongside that of heating and relevant habits and routines associated with laundering. The essential sociological context was also elicited, including economic and practical constraints and the motivations behind routines and habits that related to physical outcomes that might involve, or impinge on, laundering processes.

Twenty-two case studies (S22) were volunteered from S100, and data collected in these over a 2week period. This included the same environmental variables (equipment as described above for S100; with sensors located to avoid extraneous thermal influences), plus measurement of power consumption by appliances where possible. Householders' diaries of laundering activity and other relevant habits augmented these data. Since findings relating to appliance use have been separately published [1], this paper concentrates on measured and modelled consequences of PID relative to energy usage and humidity, and associations between IAQ and humidity.

Key constructional finishes found in S100/S22 were subjected to laboratory analysis in order to quantify their ability to function as moisture 'buffers' in varying conditions. These findings then enabled an enhanced database of properties for use in dynamic computer modelling. Only 
summarised aspects of such test data and modelling are given here. Air sampling and microbiological analysis was also undertaken in S22 - firstly to determine the overall concentration of mould spores in the air in each main room/space, and secondly to analyse presence or absence of particular mould isolates in each dwelling. Both the overall concentrations and prevalence of isolates could then be compared with prevalence of PID in order to establish any indications of consistent associations.

Duplicate air samples, using SAS super $180^{\mathrm{TM}}$, one with malt extracts agar (MEA) and the other with potato dextrose agar (PDA) as the medium for microbiological identification, were taken in 56 spaces within each home when setting up sensors and equipment (living room, bedroom(s), hall, kitchen and bathroom between 9.0 a.m. and 12 p.m.). Occupants were advised to adopt normal indoor routines before and during the sampling. Plates were incubated at $23^{\circ} \mathrm{C}$ for four days or until visible growth appeared; thereafter counted and corrected for statistical possibility of multiple particles passing through the same hole according to manufacturers' guidance. The concentration of colony forming units (CFUs) per cubic metre of sampled air is found by:

$$
X=\operatorname{Pr} \times 1000 / \mathrm{V}\left(\mathrm{CFU} / \mathrm{m}^{3}\right)
$$

where $\mathrm{V}=$ volume of air sampled (litres); $\mathrm{Pr}=$ probable count obtained by positive hole correction of $r=$ CFUs on plates.

Isolates are later sub-cultured on to MEA and PDA for further identification - in some cases to species level and in others only to genus level, based on growth and colony characteristics on media plates and microscopic examinations as described by Samson et al [16].

Thereafter, bearing in mind the size of the sample of 22 , the $\mathrm{CFU} / \mathrm{m}^{3}$ is considered as the dependent variable - firstly the arithmetic mean of all five spaces (or six if two bedrooms); secondly the arithmetic mean of living rooms and bedrooms, which were most commonly used for PID. The independent variable (IV) was based on the presence or absence of PID, classified within four categories: tumble drying dominant or only method used (IV1:TD); outside drying dominant (IV2:POD); PID dominant (IV3:PID); and a relatively equal mix of methods (IV4:mix). 
Paying due regard to a comparable study in France [17], nine other 'confounding' variables were analysed: a) season in 3-month periods (winter: December to February; spring: March to May; summer: June to August; autumn: September to November); b) level of window opening (frequent opening, moderate opening and generally shut); c) presence or absence of extract fan in kitchen; d) ditto in bathroom; e) main floor finish (carpet, laminate or timber); f) presence or absence of house plants; g) type of heating (electric or gas); h) density of occupation (number of occupants $\div$ number of apartments, where an 'apartment' is a bedroom or living room); and i) floor level (ground up to $16^{\text {th }}$ ).

Evidence of an association between concentration of $\mathrm{CFU} / \mathrm{m}^{3}$ and visible presence of mould was also explored in the analysis, as was evidence of associations between moisture levels - relative humidity $(\mathrm{RH})$ and absolute humidity $(\mathrm{AH})$ given by vapour pressure (VP) - and mould and/or $\mathrm{CFU} / \mathrm{m}^{3}$. Associations between $\mathrm{CO}_{2}$ as the indicator of $\mathrm{IAQ}$ and moisture levels was also checked over daily cycles, together with presence of PID and moisture levels, using information from diaries, and cross-checking with measurements of power consumption by washing machines. Dust samples were not collected, the aim rather to use measured moisture and temperature as an indicator of potentially large dust mite populations.

\section{Results}

\subsection{Housing provision}

The varying characteristics of a wide range of housing types influences the diversity of drying methods adopted. PID was prevalent, but generally lacked effective means of isolating and exhausting moisture, mould spores and any associated VOCs (not included in EADL). Many of the $\mathrm{S} 100$ respondents perceived drying as a problem or issue.

There was a paucity of dedicated indoor drying spaces, utility rooms or other suitable places for PID. Only four S100 respondents had drying cupboards in use. Two of these had vents fitted and one mechanical extraction; a combination boiler and hot service pipes helped to heat another (naturally ventilated); and one respondent whose space had no vents and no heating perceived a build-up of smells inside it. The declared time for drying by each respondent was lengthy at 24 hours, but this probably reflected the time clothing was left hanging rather than that needed for 
drying. Most of the dwellings surveyed could be adapted to provide a suitable drying cupboard, sometimes by restoration to original use. Another five had conservatories or sunspaces used for drying, while sixty-eight declared 'no' to this question (73\% S100 responded). Only one respondent identified a designated utility room, seventy declaring 'no'. No respondent had more than one such suitable indoor drying space, and the total number of cupboards, sunspaces and utility rooms was $10 \%$ of $S 100$. Only half of the respondents declared access to outdoor or covered semi-indoor drying, and, of those, almost half indicated drawbacks including lack of security and lack of line-space. Again, there is scope for improving existing provision.

\subsection{Environmental context}

The context as found in the sample militates against PID and ironing. The coexistence of poor air quality and high moisture levels indicate poor ventilation control relative to intensity of occupation, with high ambient humidity an added, partly seasonal, factor.

The initial daytime 'snapshot' readings for S100 households indicated environments that cannot readily accommodate additional moisture inputs from laundering activities. Table 1 highlights that vapour pressure (VP) averages for each room are above desirable maxima in terms of dust mite growth of $1.13 \mathrm{kPa}$ or $7 \mathrm{~g} / \mathrm{kg}$ mixing ratio [18; 19]. Correspondingly, averages are mainly above the 'critical equilibrium humidity' (CEH) [20;21; 22], a curve with $\mathrm{RH}$ as a function of temperature. The $\mathrm{CO}_{2}$ averages also give cause for concern and indicate that it is possible, and perhaps likely, to under-ventilate dwellings that are not particularly airtight; noting that $1,000 \mathrm{ppm} \mathrm{CO}_{2}$ corresponds with the UK CIBSE Guide, 1986, standard of 8 I/s for each occupant present [23]. Table 2 shows that VP means for living rooms and bedrooms are higher for S22 monitored over two weeks, despite a seasonal shift of emphasis from winter (approximately a third of 100) to summer (approximately a third of 22). The mean maxima VP for this smaller group are some $50 \%$ higher than the equivalent spot means for the cohort of 100 .

The mean values for bedrooms in S22 are above CEH for excess dust mite growth (RH $57 \%$, temperature $\left.17.7^{\circ} \mathrm{C}\right)$, while those for living rooms are slightly below $\mathrm{CEH}(\mathrm{RH} 51.4 \%$, temperature $\left.19.4^{\circ} \mathrm{C}\right)$. Individually, more than half of the monitored bedrooms $(52 \%)$ were above $\mathrm{CEH}$, with autumn predominating; while for those below $\mathrm{CEH}$, summer and spring predominated. This 
compares with sixteen above the $1.13 \mathrm{kPa}$ threshold, but three of these were only slightly above. In other words, the absolute moisture limit of $1.13 \mathrm{kPa}$ or $7 \mathrm{~g} / \mathrm{kg}$ compares reasonably well with $\mathrm{CEH}$. Eight of the living rooms were also above $\mathrm{CEH}$, again with autumn cases dominant, but twice as many were above $1.13 \mathrm{kPa}$. The reason for this disparity is that living rooms averaged higher temperatures. However, as most of those that were below $\mathrm{CEH}$ were monitored in spring or summer, the data suggest that if all surveys had occurred in autumn or winter, the problem of excessive humidity relative to dust mites would have been worse (only two homes were monitored during winter).

Also, in cases where mean $\mathrm{RH}$ and temperature fall comfortably below $\mathrm{CEH}$, the situation often reverses for a significant part of the 24-hour cycle - say in evenings when living rooms are occupied intensively, or bedrooms overnight. For example, case study No. 22 (CS22) in January had a low mean locus for $\mathrm{RH}$ plotted as a function of temperature in the living room $(43.5 \%$, $20.6^{\circ} \mathrm{C}$ ). But for 3.5 hours one evening, mean $\mathrm{RH}$ was $70.2 \%$ and temperature $23.5^{\circ} \mathrm{C}$, mean $\mathrm{CO}_{2}$ 2,846 ppm; and above $\mathrm{CEH}$ throughout this period with $\mathrm{RH}$ peaking at $83.2 \%$. Similarly a bedroom in CS7 overnight in April averaged $58.8 \% \mathrm{RH}$, temperature $21.3^{\circ} \mathrm{C}$ and $\mathrm{CO}_{2} 2,328 \mathrm{ppm}$, putting it well above $\mathrm{CEH}$ when its 24-hour average was below.

Table 2 may be compared with Table 3, indicating relativities for indoor air quality (IAQ), vapour pressure (VP), visible mould (M), colony forming unit (CFU) concentration, and drying method. In cases where the $\mathrm{RH}$, plotted as a function of temperature, remains consistently below $\mathrm{CEH}$, e.g. CS17, there are other consequences - in this case liberal opening of windows while heating is still used during spring. Indeed, it would appear that keeping below CEH is often reliant on this factor other than in summer - three cases for living rooms and four for bedrooms.

Such examples illustrate the inherent weakness of encapsulating arithmetic means (as Table 2), or indeed other averages such as medians or geometric means. At some point, we need to investigate the particular, including maxima and minima at particular times of the day and varying relativity between temperature and moisture. Table 2 simply gives a sense of the range of averages, as does Table 3 in terms of what these signify in a subjective broad-brush manner. 
The seasonal shift of emphasis from winter to summer, comparing initial S100 visits and S22 monitoring, is reflected in the latter's lower mean $\mathrm{CO}_{2}$ values (living rooms $22 \%$ less; bedrooms $12 \%$ less); but S22 mean maxima are significantly higher than average S100 'snapshot' values (living rooms $87 \%$ more; bedrooms $108 \%$ more) and bedroom maxima reflect poor IAQ overnight.

The association between high $\mathrm{CO}_{2}$ and high moisture was particularly evident in surges attributed to intense periods of occupation, accompanied by a rise in temperature - e.g. Fig.1, monitored bedroom in CS2. RH maxima usually correspond with maximum absolute moisture levels, and $\mathrm{CO}_{2}, \mathrm{VP}, \mathrm{RH}$ and temperature can be high simultaneously - e.g. CS2 bedroom on $6^{\text {th }}$ January during early evening: $4,031 \mathrm{ppm}, 2.5 \mathrm{kPa}, 84.8 \%, 23.8^{\circ} \mathrm{C}$, within a 10 -minute slot. Generally, moisture peaks occur during evenings in living rooms and overnight in bedrooms.

It is known that there may be significant variations of $\mathrm{CO}_{2}$ measurements within a room - e.g. up to 400 ppm during an occupancy build-up in one field study [24]; and more in a controlled experiment in a naturally ventilated room, particularly vertically [25]. In the Glasgow cases there was a general consistency between $\mathrm{CO}_{2}$ levels in different rooms of dwellings. Since the emphasis is on $\mathrm{CO}_{2}$ as an indicator of 'bad company', rather than of stuffiness per se, and since occupancy surges during daily cyclical measurements over 2-week periods conform to expectations from field data [24], any variations of $\mathrm{CO}_{2}$ within rooms above and below the measured values are unlikely to be misleading in terms of inferences.

Although the ability of PID to raise moisture levels was often masked or partly masked by quickacting influences such as presence of occupants (Fig. 1), the typical impact overnight in their absence was identified - indicated by falling $\mathrm{CO}_{2}$ contrasting with a PID-induced rise in vapour pressure of approximately $0.38 \mathrm{kPa}$ and a rise in temperature due to the night-storage heating (Fig. 2: living room). However, the level of moisture anticipated experimentally (3.5 below), suggests that RH and VP should increase more significantly. The difference could be due to absorption within fabric and furnishing, higher air-change rate, migration within the dwelling, and/or less moisture to be released. The same would apply the case of ironing, where tests indicated a lower rise in VP $(0.15-0.2 \mathrm{kPa})$. Such increases, in particular due to PID, would not be overly consequential if it were not for the prevailing high levels, and an evident association with higher mould spore counts (3.4 below). 
Those who passively dried indoors, with windows liberally opened during autumn, tended to have rather high absolute moisture levels, even though the air quality indicated by $\mathrm{CO}_{2}$ was reasonably good, at least on average - e.g. CS3 (Table 2), $19^{\text {th }}$ October to $3^{\text {rd }}$ November, with a living and two bedrooms mean VP of $1.31 \mathrm{kPa}$ and $\mathrm{CO}_{2}$ of $719 \mathrm{ppm}$. This indicated that better control of ventilation was required, both to exhaust moist air at source, and to limit ingress of damp ambient air at certain times of the year and/or in humid weather conditions.

Migration of moisture from one space to another indicates similarly poor control of ventilation. For example in a kitchen-living adjacency in CS7, a peak of $2.4 \mathrm{kPa}(83 \% \mathrm{RH})$ at 17.30 is reflected 20 minutes later by $1.9 \mathrm{kPa}(73 \% \mathrm{RH})$ in the living room, where further moisture from PID would add to an already poor situation.

\subsection{Seasonal influences and PID-related control decisions}

Respondents from S100 had an optimistic view of 'access to sunlight' and 'good access to sunshine'. Where this initial view coincided with those in S22 who passively dried within rooms, it was found that actual conditions on the first day of monitoring, the day of air sampling, were in fact frequently sunny. But perceptual responses to the prevailing weather were capable of increasing energy use or compromising IAQ - one issue being windows.

Where perceptions lead to window opening while heating is still used, or even boosted, and PID is occurring, it will have an impact on energy for space heating that can at least partly be attributed to the issue of drying. For example, out of 34 households interviewed in winter (December to February), 28 (82\%) passively dried within their homes, often in more than one space. Of these, 19 (68\% of 28$)$ located airers on/near heat emitters, and $6(21 \%$ of 28$)$ of these turned heat up to speed the drying process. In terms of moisture mitigation, 8 (31\% of 26 applicable cases) said that a window was always open while drying, and a further $13(50 \%$ of 26$)$ occasionally opened windows. Some 'occasional' window openers coincided with heat-to-dry boosters, but none of those that 'always' opened windows also boosted heat. Similar tendencies were found in spring and autumn. The greater proportion of the 'heat boosted' category occurred in spring (mean ambient temperatures lower than autumn by $1.64 \mathrm{~K}$ in Glasgow), while the greater proportion of the 'window always open' category were in autumn. 
Using the CS2 family size of 7 as a winter example, with windows liberally opened, a BREDEMrefined [28], 2-zone, steady-state analysis adjusted for January in Glasgow, compared three scenarios. Dehumidification was by ventilation only for an intermediate terrace location and the TH07 Scottish Technical Handbooks [27] default U-value standards, floor area of $114.5 \mathrm{~m}^{2}$ : a) Mechanical ventilation with heat recovery (MVHR), and 'all-day' 16-hour heating regime to $21^{\circ} \mathrm{C}$ demand temperature (mean $20.4^{\circ} \mathrm{C}$ in living room of CS2 for 10 wash days); zone 1 (living plus kitchen) and zone 2 (rest of house) respective values of 0.39 and $0,34 \mathrm{ac} / \mathrm{h}: 21 \mathrm{kWh} /$ day. b) No heat recovery, but with the same heating regime and natural/mechanical air change rates of 1.00 and $1.07 \mathrm{ac} / \mathrm{h}$ in zones 1 and 2 respectively: $42 \mathrm{kWh} /$ day

c) No heat recovery, ventilation rates doubled, demand temperature raised to $23^{\circ} \mathrm{C}: 88 \mathrm{kWh} / \mathrm{day}$. Broadly, we can see that the energy demand doubles, moving from MVHR to natural/exhaust ventilation; and more than doubles again when thermostat setting is raised by two degrees, while the ventilation rate doubles. Such differences would increase if the energy efficiency were below that assumed - i.e. below TH07 standard - and/or in an end-of-terrace or semi-detached location. Dynamic computer modelling [28] of a notional semi-detached house for a winter week, with ventilation increased to approximate to CS2 PID conditions, compares reassuringly with the above BREDEM-based analysis. Modelling also examined the impact over a year for such a dwelling, washing at the relatively extreme rate of CS2 (2 adults; 5 children; all PID), with drying confined to 7-hour spells in the living room, while thermostat setting was boosted by $3 \mathrm{~K}$ and windows left ajar (air change increased by $3.6 \mathrm{ac} / \mathrm{h}$ ). The simulation predicted a rise of 3,595 kWh from about 7,000 kWh - more than $50 \%$. Using the same notional area to that of CS2 for a 7person family $\left(114.5 \mathrm{~m}^{2}\right)$, this suggests at least $30 \mathrm{kWh} / \mathrm{m}^{2}$ increase, partly or mainly due to PID; but for a more typical 5-person house envisaged in the model $\left(89.9 \mathrm{~m}^{2}\right)$ the increase would be approximately $40 \mathrm{kWh} / \mathrm{m}^{2}$.

Annual tumble-drying (TD), at the same extreme frequency as the above CS2 PID scenario, is estimated to consume $1,404 \mathrm{kWh}$, or $16 \mathrm{kWh} / \mathrm{m}^{2}$. However, this is the electricity consumed at the point of delivery. With a generation and grid efficiency coefficient of $0.365^{2}$ [29], primary consumption would be $3,847 \mathrm{kWh}$ or $43 \mathrm{kWh} / \mathrm{m}^{2}$ for an $89.9 \mathrm{~m}^{2}$ house. Assuming all additional modelled space heating of $3,595 \mathrm{kWh}$ is by gas and $85 \%$ attributable to PID, a primary to 
delivered efficiency of 0.9 and a boiler efficiency of 0.9 , the primary addition for passive drying to space heating is $3,773 \mathrm{kWh}$. Approximate parity with TD is now evident. However, critically, both are unsustainably excessive. Additionally, appliances with flexible hoses to exhaust out of open windows (most common method in Glasgow survey) may add to space heating demand in the same way as for PID [1], and so comparison of TD -consumption with PID-based simulations is not 'like for like'. Moreover, the estimate, four times greater than the DEFRA average of $354 \mathrm{kWh}$ [32], is based on a large household with five children (CS 2). Given that volume of washing, had a tumble dryer been employed, it is likely to have been only for some of the washing.

\subsection{Moisture, visible mould and mould spores}

The practice of opening windows while heating is used also impinges on IAQ in terms of $\mathrm{CO}_{2}$ levels, humidity and spore concentration $\left(\mathrm{CFU} / \mathrm{m}^{3}\right)$. In $\mathrm{S} 22$, autumn and winter have the highest $\mathrm{CO}_{2}$ and absolute moisture levels (VP) are highest in autumn, followed by summer - some ambient influence confirmed by analysis of particular cases. Indoor $\mathrm{CFU} / \mathrm{m}^{3}$ is highest in winter and spring compared with the two warmer seasons of summer and autumn, when one expects the highest values outdoors [31] - median values in an Austrian survey of $1,000 \mathrm{CFU} / \mathrm{m}^{3}$ in summer cf. 360 in autumn, 250 in spring and 80 in winter. Respective summer and autumn indoor means for S22 were 752 and $638 \mathrm{CFU} / \mathrm{m}^{3}$, and those for winter and spring were 1,068 and 1,347.

Three key issues are apparent. Firstly, there is no consistency between visible mould and spore count (Tables 2 and 3), noting the critical $\mathrm{RH}$ required for mould growth on various materials as a function of temperature and exposure time [34]. Secondly, there is a general lack of effective ventilation to avoid excessive $\mathrm{RH}$ spikes due to activities involving rapid moisture production. Thirdly, despite several confounding variables, the indications are that PID with slowly drying laundry has an association with both relatively high total spore concentration and a higher incidence of mould isolates, in particular ones classed as hydrophilic or tertiary (water activity or $\left.a_{w}>0.90\right)$. Depending on particular mould isolates, the third finding could constitute a potential health hazard for atopic occupants (See 4.1). We may note that Finnish research stresses that "exposure is the integral of the concentration over time" and also the water activity $\left(a_{w}\right)$ range falls with rising temperature; for example, Aspergillus versicolor 0.87 at $12^{\circ} \mathrm{C}$, but only 0.79 at $18^{\circ} \mathrm{C}$ 
[39]. This aligns with fuel poverty, where typically low temperatures and high $\mathrm{RH}$ provide more risk of mould growth.

Regarding ventilation control, it was evident that awareness of built-in mechanical extract in highrise towers was poor - of 8 out of S22 case studies in high-rise towers, only half responded correctly. Overall awareness of manual versus automated control was similarly poor in S100 - of 64 with mechanical exhaust in bathrooms, only13 knew this to be so. Also more than one fifth of these households passively dried indoors in the absence of any mechanical extract, with ventilation control reliant on window opening and operation of their trickle vents (no dwellings with MVHR). There was also no convincing evidence that presence of extract fans mitigated presence of mould. More than half of the 100 households had mould in at least one room, and nearly $80 \%$ of these had at least one mechanical extract.

Ubiquitous trickle vents were not used in almost half the households in S100. The majority of the remainder, 31 , claimed to regularly adjust the vents, while 20 said they did this occasionally. Just over one fifth (21) said that they were not sure how to operate the vents and more (28) gave other reasons for non-use including obstructions to accessibility and non-functionality. Of the 12 in S22 that used trickle vents, three never adjusted and two occasionally adjusted them. We may conclude that trickle vents are a poor provision. More generally, the relatively high moisture levels and unsatisfactory IAQ found relates to inadequate means, inappropriate usage and poor awareness of natural and mechanical ventilation control.

The lack of consistent association between total indoor airborne mould spore concentration $\left(\mathrm{CFU} / \mathrm{m}^{3}\right)$ and surface mould (Table 2) accords with work in Victoria, Australia [34]: "It is very difficult to explain why significantly smaller viable spore concentrations would be found in rooms with visible mould growth." However, this earlier study found that visible mould or condensation corresponded with Cladosporium spores, classified as mesophilic [35; 36]. They are also known to colonise on interior surfaces [37] even though spore levels indoors are generally driven by outdoor concentrations [38]. Penicillium is a dominant indoor mould [40] and also mesophilic [35; 36], with concentrations found in the Australian study to increase where walls and floors were not insulated [34]. The analysed sampling in Glasgow (20 out of 22) did not provide a similar association between airborne presence of Cladosporium and visible mould: 11 with both 
Cladosporium and mould present; 7 with Cladosporium present but no visible mould; and 2 where neither Cladosporium nor mould is present. As Penicillium species are present in all but one of these homes, and Aspergillus, another dominant indoor species [38], is present in all of them, it was self-evidently not possible to associate either of them with mouldiness.

However, the Glasgow study indicates a marked association between presence of PID and CFU concentration, which consistently tends to be higher when PID is present than absent. Fig. 3 shows the 'boxplot' for 4 independent variables: predominant use of: tumble drying (IV1:TD); passive outdoor drying (IV2:POD); passive indoor drying (IV3:PID); and mixed methods (IV4:Mix).

Tables 4 and 5 give means and standard deviations for CFU for all rooms and the means for living and bedrooms in each of the four categories of independent variable. The difference between drying methods is statistically significant overall for both as per Table $6(F(3,18)=5.29$, $p=0.009)$ and $F(3,18)=5.14, p=0.01)$. Grouping everything that is not Independent Variable $=$ IV3:PID together as IV (IV1:TD, IV2:POD and IV4:mix) = 0, with a new variable IV3:PID $=1$, the means and t-test, Tables $7-8$, show that the difference is highly significant.

Multiple regression for seven potential confounding variables indicated nothing of significance, Table 9: season (spring most significant), floor covering (laminate/timber or carpet), house plants (present or absent), heating (gas or electricity), fan in kitchen (present or absent), fan in bathroom (present or absent), windows (open or closed; no difference between wide open and ajar). None of the p-values (Sig: right hand column) have high significance other than IV3:PID, with that for the kitchen fan coming closest to the $10 \%$ range. Note that an investigation elsewhere into floor coverings of varying types, ages, dustiness and seasons indicated differences in spore concentrations [39], although evidently not of significance in the Glasgow study.

Tests were also done to establish whether intensity of occupation might be significant: firstly, CFU-all against the number of occupants; secondly comparing dwellings with adults only to those with children; thirdly, the density of occupation taken as the ratio of all occupants to number of apartments (bedrooms + living room). Again this showed no significance for occupation factors, relative to IV1-4. While regression showed IV3:PID to be significant with $p$-value $=0.001$, that for density was negative at $p=0.093-$ i.e. higher densities and fewer mould spores, which has no 
evident logic other than a random paradox. Finally, no statistical significance was found for the independent variables IV1-4 relative to the moisture variables (RH or VP).

The analysis carried out to identify mould isolates in 20 of S22 cases included 6 of the 9 in IV3:PID where the spore concentration averaged over $1,000 \mathrm{CFU} / \mathrm{m}^{3}$ (mean 1,616 CFU $/ \mathrm{m}^{3}$ ); and is compared with 14 others (all not in the IV3:PID set except outlier CS14) where concentration averaged less than $1,000 \mathrm{CFU} / \mathrm{m}^{3}$ (mean $697 \mathrm{CFU} / \mathrm{m}^{3}$ ). Results (Table 10) indicated a greater prevalence of the 19 identified tertiary mould isolates for the six homes with the higher CFU concentration compared with the fourteen homes averaging less than $1,000 \mathrm{CFU} / \mathrm{m}^{3}$. If CS 14 in the IV3:PID group is included in the 'high' CFU set, the respective gaps widen slightly further.

Taking all tertiary, secondary and primary isolates in the IV3:PID cases (total 49), the IV3:PID set of six case studies remains slightly higher than the remaining fourteen. Averages for 16 secondary isolates reverse this trend slightly. Nevertheless, in two cases where presence of specific isolates is high in both groups - e.g. Aureabasidium pullulans and Ucladium chartarum $[35 ; 36]$ - the IV3:PID set has a marginally greater proportion.

Further, although samples are statistically small, there is a proportionately stronger presence of particular tertiary isolates in the IV3:PID cases. Table 11 summarises this for Acremonium strictum, Botrytis cinerea [40], Chaetomium spp. [41; 42 ${ }^{5}$ ], Memnoniella echinata [43], Phoma herbarum, Rhizopus stolonifer and Stachybotrys chartarum [35; 36]. For other isolates there is a universally high or nearly equal, but lower, presence - for example, Mucor spp. [42; 43], Trichoderma spp. [45] and Aspergillus fumigatus [45].

\subsection{Hygrothermal role for lining materials - modelling a drying cupboard}

Laboratory analysis in support of dynamic energy and moisture modelling overlapped with, and was informed by, the data-collection and analysis stages of the fieldwork. One emergent aim was to establish whether hygroscopic materials could help to flatten $\mathrm{RH}$ profiles in small and discrete drying spaces, especially in the initial drying stage, and hence inhibit $\mathrm{RH}$ peaks for a given rate of extract. Another was to establish the same potential worth in terms of mitigating moistureproducing activities in larger rooms (e.g. occupants of ill-ventilated bedrooms overnight, and ultimately responsible for a proportion of laundering). 
A monitored PID exercise in a domestic setting was carried out in association with laboratory experiments to find absorption characteristics of various building materials. In the former, VP plateaus at approximately $1.2 \mathrm{kPa}$ after 4 hours having started at $0.97 \mathrm{kPa}$, while temperature started at approximately $18.5^{\circ} \mathrm{C}$, rose to $22^{\circ} \mathrm{C}$ at completion of drying. The exercise indicated that a typical 15 item load, dry weight $3.76 \mathrm{~kg}$, releases moisture at $285 \mathrm{~g} / \mathrm{h}$ over $7 \mathrm{hrs}$, totalling approximately $2.0 \mathrm{~kg}$ or litres. Similarly, 17 items (2 additional cord equivalents), dry weight 4.84 $\mathrm{kg}$, releases moisture at $355 \mathrm{~g} / \mathrm{h}$ over $7 \mathrm{hrs}$ totals approximately $2.5 \mathrm{~kg}$ or litres. One may compare this with the range $2.2-2.95 \mathrm{~kg}$ given for a $3.6 \mathrm{~kg}$ load in the late $1980 \mathrm{~s}$ [46], and more recently cited [47]. Given higher spin rates today compared with 1988, the PID test values appear realistic. Also, approximately $88 \%$ of the moisture is released in the first 4 hours of drying in the test conditions - reasonably warm and well ventilated.

Initial laboratory tests indicated that differences in moisture buffering capacity between certain materials at $65 \% \mathrm{RH}$ might justify their use as linings to a drying cupboard. However long-term equilibrium moisture content of respective hygroscopic materials can be deceptive compared with the moisture absorption by the same set of materials over a short time period. In an equilibrium test (criteria include three weight measurements at least 24 hours apart), at $65 \% \mathrm{RH}$, unsealed cork absorbs $37 \mathrm{~g} / \mathrm{kg}$, a proprietary clay board $24.5 \mathrm{~g} / \mathrm{kg}$ and matt-painted plasterboard $4.5 \mathrm{~g} / \mathrm{kg}$. However, at $65 \% \mathrm{RH}$, short-term gain of $7.0 \mathrm{~m}^{2}$ of the same three materials (as in a $1.75 \mathrm{~m}^{3}$ drying cupboard) indicates clay board absorption rate of $61 \mathrm{~g} / \mathrm{h}(0.9 \mathrm{~g} / \mathrm{kg} . \mathrm{h})$ compared with $7 \mathrm{~g} / \mathrm{h}$ $(0.7 \mathrm{~g} / \mathrm{kg} . \mathrm{h})$ for cork and $12 \mathrm{~g} / \mathrm{h}(0.2 \mathrm{~g} / \mathrm{kg} . \mathrm{h})$ for plasterboard. Values also vary exponentially with $\mathrm{RH}$. At the undesirably high moisture level of $90 \% \mathrm{RH}$, the clay board is calculated to absorb 262 $\mathrm{g} / \mathrm{h}$, plasterboard $112 \mathrm{~g} / \mathrm{h}$ and cork $42 \mathrm{~g} / \mathrm{h}$; and at $75 \% \mathrm{RH}$, approximately $117 \mathrm{~g} / \mathrm{h}, 36 \mathrm{~g} / \mathrm{h}$ and 16 $\mathrm{g} / \mathrm{h}$. Returning to $65 \% \mathrm{RH}$, this suggests that such moisture buffering could absorb $244 \mathrm{~g}$ of moisture over 4 hours, or $14 \%$ of the first 4 hours of drying for a washing load with moisture emission of $2.0 \mathrm{~kg}(88 \%$ of $2.0 \mathrm{~kg}=1,760 \mathrm{~g} \div 244 \mathrm{~g}=13.9 \%)$.

However, dynamic modelling of a $1.75 \mathrm{~m}^{3}$ drying cupboard indicates greater complexity [28]. Damp washing initiates evaporative cooling whilst adding moisture. A series of simulations at 15 I/s, with simple extract and MVHR operating continuously showed better results than intermittent, humidistat-switched control, but still with $\mathrm{RH}$ maxima invoking risk of condensation and mould. 
Continuous extract lowered $\mathrm{RH}$, but consumed considerably more energy than intermittent, whether with or without heat recovery - e.g. respectively 19 kWh cf. 12 kWh and 57 kWh cf. 22 $\mathrm{kWh}$ and for a winter week and unpainted plasterboard lining.

Further modelling at $30 \mathrm{l} / \mathrm{s}$ indicated environmental viability, with the extreme condition in summer having a period of 24 hours with ambient $\mathrm{RH}$ averaging approximately $90 \%$. This caused $\mathrm{RH}$ in the drying cupboard to exceed $70 \%$ for a 4 -hour period while a fan operated at $30 \mathrm{l} / \mathrm{s}$. Research in the Netherlands explores the risk of intermittent spikes in RH causing mould growth $[32 ; 48 ; 49$; 50]. However, despite the cautionary note, the 4-hour surge was for a non-hygroscopic lining, with moisture absorption in the surfaces not explicitly modelled. Simulations of specific moistureabsorbing materials such as clay board were ongoing at the end of the EADL study ${ }^{4}$. Since the laboratory experiments indicated that clay board would absorb 3.25 time more than painted plasterboard at $75 \% \mathrm{RH}$, the simulations may have some damping effect on occasional summer peaks. However, a confined space and rapid exhaust seem likely to militate against this.

\section{Discussion: towards healthy, energy-efficient drying}

\subsection{Health implications and reliability of results}

The methodology did not include dust sampling and the impact of moisture from PID was difficult to isolate in most instances. Nevertheless, the results show that humidity levels are frequently above accepted thresholds for excessive numbers of dust mites, to which consequent allergen exposure and asthma exacerbation in sensitised individuals has been causally linked [51].

With respect to heath implications for, and sensitivity to, mould isolates, it is stated that an example such as Aspergillus fumigatus "causes invasive allergenic disease" where immune systems are vulnerable [52; 53]; and "can be very dangerous" [54]. Both Aspergillus species, present in all the dwellings sampled in Glasgow, and Penicillium, present in all but one, "contaminate indoor spaces biologically" and "are important sources of allergens" [31].

Work in Finland [33] qualified micro-organisms as contaminants "if their presence is harmful and unwanted". In this vein, research in West Virginia [55] cautions "allergen content in fungal extracts is highly variable" [56], with variability in particular species such as Alternaria alternata, 
Aspergillus fumigatus and Cladosporium herbarum [57]. It also found $6 \%$ sensitivity to Acremonium strictum, where all patients in a clinic "had symptoms consistent with allergic rhinitis or asthma"; while another USA study failed to confirm Acremonium strictum as significant [58]. Again, the West Virginian work found sensitisation to Stachybotrys chartarum to be low at 3\%, aligning with other work [59; 60].

Finnish research supplied "the direct link between exposure and health symptoms", via experiments with both hospital patients and mice, confirming a high dependence on the atopic status of these subjects in terms of the inflammatory reaction $[61 ; 62 ; 63]$. UK research [64], although acknowledging relevance of atopic subjects, lays more stress on health risks from low concentrations of mould - viz. 'Satratoxin H' produced by Stachybotrys chartarum in damp houses capable of causing "necrosis and haemorrhage in many organs"; and cites earlier and more recent work regarding health impacts $[65 ; 66]$. More recent work includes Phoma Herbarum, Rhizopus stolonifer and Stachybotrys chartarum in a set "strongly associated with odds of respiratory illnesses" [36]. A cluster of cases of pulmonary hemosiderosis in infants in Cleveland, Ohio, led to the isolation Memnoniella echinata, known to be closely related to Stachybotrys [67]. A study of airborne Botrytis cinerea [68] found significant sensitivity in atopic subjects - e.g. $24 \%$ of suspected mould allergic children with asthma in Finland, and $52 \%$ with suspected mould allergic patients in the USA; both with 'radioallergosorbent' tests (RAST).

Hence there is variable health significance of certain hydrophilic mould isolates found among the IV3:PID case studies. There is also evidence of an association between sensitisation to a mould species classed as mesophilic, Aureobasidium pullulans [35; 36], and severity of asthma [69]. Although it is also regarded as hydrophilic [70], the lower classification is adopted in EADL. Another study [71] links Exophilia jeanselmei to bloodstream infection, normally of low virulence; but confirmation of the $a_{w}$ ratio for this species has proved illusive, and accordingly it has also been deemed mesophilic or secondary. Ucladium chartarum is another species that appears to be mesophilic, but on the cusp of hydrophilic, with an $a_{w}$ ratio of $0.89[35 ; 36]$. This species is also associated with type 1 hay fever [72].

The observations here are predicated on the taxonomy of isolates into their primary, secondary and tertiary categories, in particular the last. The tertiary group of a further 9 isolates in addition to 
those already cited (total 19 tertiary isolates) comprises: Acremonium spp. [40]; Alternaria alternata [45]; Chaetomium globosum [36; 40]; Fusarium culmorum [73]; Fusarium sporotrichides [74]; Geostrichum candidum [75]; Mucor plumbeus [35; 36; 45]; Mucor racemosus [40]; and Phoma glomerata [70]. For isolates deemed secondary, the following 13, in addition to 3 cited above in connection with health risk, are: Aspergillus flavus, A. ochraceous, A. versicolor [35]; Basidiomycetes $\left[76^{6}\right]$; Ascotricha chartarum $\left[77^{6}\right]$ Cladosporium cladosporioides, C. herbarum, C. sphaerospermum [35]; Curvularia geniculata ${ }^{7}$; Epicoccum nigrum [35; 36]; Fusarium spp. ${ }^{8}$; Fusarium solani [35]; and Scopulariopsis brevicaulis [40; 78].

The review of the presence or absence of specific mould species validates the relevance of higher overall airborne spore concentrations associated with PID. This group had a proportionately greater presence of hydrophilic species in comparison to other forms of drying (both average for set of hydrophilic isolates identified, and proportion of specific isolates), approximate parity for the mesophilic species and a greater proportion of total isolates. It has long been recognised that $\mathrm{CO}_{2}$ is a useful IAQ indicator of 'bad company', and remains so today [3]. However, in this case CFU concentration is not necessarily recognized by $\mathrm{CO}_{2}$ since PID may occur in the absence of the occupants. Moreover, overall CFU $/ \mathrm{m}^{3}$ cannot be easily or cheaply measured, let alone concentrations of mould isolates.

The literature reviewed here suggests that the severity of health risk attributable to airborne spores varies considerably. Accepting this caveat, the range of values of spore counts and isolates associated with the presence of PID is of a level whereby the health of atopic occupants (those vulnerable to hay fever, asthma and eczema) could be adversely affected. Although not as relevant as presence or absence of specific species, the arithmetic mean total concentration is over three times a Finnish health limit of $500 \mathrm{CFU} / \mathrm{m}^{3}$ [79], in turn supported by earlier Danish research [80]. Further, the Institute of Medicine in the USA predicts that $6-10 \%$ of the population and $15-55 \%$ of atopics are sensitized to fungal allergens [51]. This range is commensurate with other contemporaneous work [81], quoting " 20 to $30 \%$ among atopic individuals and up to $6 \%$ in the general population". Later commentary adheres to these broad estimates, and reports on skin-prick tests at 29 European allergy centres, which gave a range of $1.3-52 \%$ allergy and 
median of $18.8 \%$ for airborne Botrytis cinerea, comparing this to a $40.5 \%$ median for allergic response to at least one fungal species. [67].

An underlying hypothesis supported by the evidence is that damp textiles drying slowly over a period of several hours (up to a day or more in moist, cool conditions) tends to be more potent, in terms of fostering fungal spores, compared with other producers of moisture that are more concentrated but in shorter durations (also more convectively driven and often exhausted rapidly at source). The prevalence of washing cycles at or below $40^{\circ} \mathrm{C}$ may also result in spores present in dirty laundry remaining active once clean $[84 ; 85 ; 86]^{9}$. Virtually all - 95\% (89 out of 94 ) in S100 - used $40^{\circ} \mathrm{C}$ or $30^{\circ} \mathrm{C}$ as the most frequent wash temperature, and $39 \%$ (37 out of 94 ) $30^{\circ} \mathrm{C}$. In the S22 IV3:PID set exceeding $1,000 \mathrm{CFU} / \mathrm{m}^{3}$ there are three at $30^{\circ} \mathrm{C}$, three at $40^{\circ} \mathrm{C}$ and one at $60^{\circ} \mathrm{C}$, the last having the lowest CFU count of these seven households.

However, doubt can linger as to coincidence in the statistical analysis of a small sample. Geometric means help to correct the bias of outliers shown in the 'boxplot', Fig. 3 (i.e. are more representative than arithmetic means). In the eight IV1:TD case studies, the geometric mean for living rooms and bedrooms is $644 \mathrm{CFU} / \mathrm{m}^{3}$ (2.7\% lower than arithmetic mean 662). For the nine IV3:PID homes, the geometric mean is $1,398 \mathrm{CFU} / \mathrm{m}^{3}$ ( $8.5 \%$ lower than arithmetic mean 1,528$)$.

It is also reassuring to find a rationale for particular outliers masked in the averages above, but evident in Fig. 3. For example, in CS6, with no significant surges in humidity corresponding to tumble-drying cycles, all rooms have very high overall humidity and poor IAQ, the latter suggesting that ambient influence is low. Means for $\mathrm{VP}, \mathrm{RH}$ and $\mathrm{CO}_{2}$ are respectively $1.54 \mathrm{kPa}$, $73.6 \%$ and 2,046 ppm for living room and bedrooms combined; and equivalent mean maxima are $2.01 \mathrm{kPa}, 87.5 \%$ and 5,000 ppm (instrument limit). But spore counts exceed $1,000 \mathrm{CFU} / \mathrm{m}^{3}$ in all spaces apart from the kitchen. Nevertheless, the count of tertiary isolates is significantly lower than the average for the PID set (3.0 compared to 6.5), and even the number of secondary isolates is below average. Rather than simply being exceptions, knowledge of specific circumstances also helps to explain other outliers (e.g. CS7 and CS18 high; CS14 low), and some of the differences found between EADL in Glasgow [85] and the French study [17]. 
There is a further issue in relation to PID, outside the scope of EADL while relevant for future work and a new generation of drying cupboards ( 4.2 below) - that of water soluble VOCs increasing in concentration with increased humidity [86]. This will apply to any formaldehyde in timber particleboards and other common building or furnishing materials. Moreover, with specific regard to PID, acetaldehyde has been associated with fabric softeners in the USA [87; 88].

EADL found that many households used both biological detergents and softeners. Work in USA established a level of reported irritation to scented laundry products vented outside by tumble dryers [89]. This supports the desirability for a specific UK study in that higher numbers may experience irritation from fabric softeners within the confines of their homes linked to PID.

\subsection{Regulation and best practice}

The analysis, including laboratory work and simulations, provides evidence that the practice of PID currently compromises energy efficiency and IAQ, the latter potentially boosting dust mite populations and increasing airborne mould spore concentrations. Regarding energy, open windows and/or augmented heating may add to fuel poverty, while excessive dust mites or airborne mould spores may adversely affect health, especially for the atopic section of the population and notably including young children. Menon and Porteous [90] have summarised the regulatory status quo for PID and suggested minor changes to the wording of standards applicable to PID; these to require discrete heated and ventilated drying facilities in order to tackle the problems identified by EADL.

This prospective change aligns with a DEFRA briefing [91]: "New homes should be required to have accommodation for efficient laundry drying facilities including, where possible, space for outdoor drying and an airing cupboard served by MVHR." However, the EADL simulations noted above indicate that heating loads for dedicated drying cupboards remain significant. To offset these, efforts should be made to exploit fortuitous heat from internal sources and/or solar heat. Examples in the former case are transmitted heat from 'main-space' radiators sited on the outside of drying-cupboard partitions, or from a boiler, hot water cylinder, or appliances (e.g. a freezer) in the cupboard. Solar gains might be in the form of direct passive gain through glazing, or indirect, say from a solar air collector. Both are known to perform well in Scotland [92]. Direct passive 
solar gain can also be exploited externally together with protection from precipitation transparent canopies - or indirectly making use of active or hybrid solar techniques - communal facilities providing an opportunity to remove the drying cycle of laundering from the home [93; 94]. In addition to minor changes to UK and Scottish Government statutory building standards to meet these aspirations, manufacturers of MVHR systems may have to modify their current practice and product range. Fan power would depend on designing the system to avoid excessive effective length and hence pressure drop. Since MVHR has been simulated as a superior option to simple extract, recently published information with respect to performance in practice is relevant [95; 96]. This indicates that successful operation is dependent on effective design, quality of installation, appropriate use (in turn reliant on specified control system) and regular maintenance; and that often one or more of these aspects undermines the efficacy of the system.

Completed work by others [97; 98] adds knowledge concerning moisture buffering and places dynamic moisture modelling in context. Given the stated emphasis of this paper, the intention at this stage is to give a pointer toward simple architectural solutions to the environmental and health risks brought to light by current PID custom and practice.

\section{Conclusions}

1) The combination of inadequate indoor and outdoor drying provision, coupled with prevalent poor control of ventilation and moisture migration within dwellings, means that the occupants' ad hoc use of PID in various rooms and circulation spaces has two identified and potentially undesirable environmental consequences compared with other drying methods:

a) Moisture contributes to excess dust mite growth, with a known causal association with asthma; b) Association with higher concentration of airborne mould spores (CFU/m $\left.\mathrm{m}^{3}>1,000\right)$, and greater prevalence of hydrophilic isolates; attributable to slow release of moisture and possibly partly to low-temperature washes; and potentially adding to health risk for atopic occupants.

2) Since CFUs are not simple or economic to measure on a regular basis, the only way to ensure levels are reasonably low is to remove known sources of the problem - in this case PID and very high indoor humidity for other reasons such as inadequate ventilation with intense occupation. 
3) Although epidemiological data already exists in the case of 1a), this study indicates a case for specific work to identify associations between CFU concentrations that are at least partly attributable to PID, and potential health effects, in particular to those who are prone to allergies. 4) PID is also inherently energy-profligate due to accompanying ventilation and heating habits. As it could use as much as full reliance on tumble-drying (TD) in primary energy terms, as well as diminishing quality of life, there is a strong case for healthy, energy-efficient forms of PID and TD.

5) The first four conclusions point to the need for independently heated and ventilated drying spaces - i.e. 'isolated' to improve both health-safety and energy-efficiency. This would require changes to current statutory standards of a minor nature (including larger minimum volume than present designated space), but with a potentially large economic impact.

6) Laboratory work has indicated limited potential for lining materials such as clay-board to curb humidity peaks in minimal drying spaces of this kind, in particular during exceptionally moist summer periods. But moisture buffering in larger, less rapidly ventilated, spaces could be more useful. There are also many architectural options for environmentally 'safe' PID, especially ones that exploit fortuitous heat gain and/or solar energy - thermal or electrical; the key criterion being that exhaust air does not circulate into inhabited spaces. These may be individual or shared, the latter in enhanced outdoor, semi-outdoor or fully indoor situations, including partial or full communal laundry provision, and could be added as new advisory 'best practice' standards.

7) Given the evidence of poor ventilation, there is a case for further work to study concentrations of VOCs associated with domestic laundering, in particular fabric softeners during a PID process. The case for this in the UK relates to work in northwest USA, which found chemicals such as acetaldehyde (classed as carcinogenic) emitted from drying involving softening products, as well as to moisture from PID adding to concentration of other water-soluble VOCs in various materials. 


\section{Acknowledgments:}

The team from all three research units, MEARU, RICH and ESRU, wishes to express thanks, firstly for the financial support from the Engineering and Physical Sciences Research Council (EPSRC grant reference EP/G00028X/1), and secondly for the co-operation of numerous housing associations, and the individual householders who agreed to the survey, and especially to the two-week monitoring. The team also thanks Dr Colin Hunter, Glasgow Caledonian University, for his valuable advice concerning water activity classification, Dr Vivien Swanson, Stirling University, for additional statistical guidance, and respective institutional librarians for their valuable assistance regarding the literature search for previous data and insights relevant to this study.

\section{References:}

[Prefacing note: DEFRA will appear as author in lieu of full name Department of Environment, Food and Rural Affairs or adopted logo versions such as 'defra' or 'Defra'.]

[1] Porteous, C. D. A., Sharpe, T. R., Menon, R. A., Shearer, D, Musa, H., Baker, P. H., Sanders, C. H., Strachan, P A., Kelly, N. J., and Markopoulos, A. (2012) ‘Energy and environmental appraisal of domestic laundering appliances', Building Research \& Information, 40(6): 679-699.

[2] Strachan, P. (2008), Simulation support for performance testing of building components, Building and Environment, 43(2): 228-236.

[3] Porteous, C. D. A. (2011) Ch. 8 'Sensing a Low- $\mathrm{CO}_{2}$ Historic Future', in Chemistry, Emission Control, Radioactive Pollution and Indoor Air Quality, Ed. Nicolas, A. Mazzeo, Intech, Rijeka, Croatia, pp 216-217 in 213-246.

[4] Carnelley, T., Haldane, J. S. and Anderson, A. M. (1887) IV 'The Carbonic Acid, Organic Matter, and Micro-organisms in Air, more especially of Dwellings and Schools', Philosophical Transactions of the Royal Society, Series B, 178: 71-72 in 61-111.

[5] Shove, E. (2004) 'Changing human behaviour and lifestyle: a challenge for sustainable consumption?', in The Ecological Economics of Consumption, Eds. L, A. Reisch and I. Röpke, Edward Elgar Publishing, Cheltenham, UK, pp 111-131. 
[6] Shove, E. (2003) Ch. 7 'Laundering: A system of Systems' and Ch. 8 'Laundry Habits: Integrating Practices', in Comfort, Cleanliness + Convenience, The Social Organization of Normality, Berg, Oxford, UK, and New York, USA, pp 117-157.

[7] Shove, E. (2003) 'Converging Conventions of Comfort, Cleanliness and Convenience', Journal of Consumer Policy, 26: 395-418.

[8] Isaksson, C. (2011) 'From a passive to an active house', proc. World Renewable Energy Congress 2011, 8-13 May, Linköping, Sweden, 1789-1796.

[9] Hazas, M., Friday, A. and Scott, J. (2011) 'Look Back before Leaping Forward: Four Decades of Domestic Energy Inquiry', IEEE Pervasive, January-March, 10(1): 13-19.

[10] Karresand, H. (2012) 'The Wrench in the Works: Household Behaviour and Why Energy Efficient Buildings are not Enough', proc. 2012 ACEE Summer Study on Energy Efficiency in Buildings: Fully our future with Energy Efficiency, 2011, 12-17 August, Pacific Grove, California, USA, 7.114-7.125.

[11] Hasselaar, E. (2008) 'Health risk associated with passive houses: An exploration', proc. Indoor Air 2008, 17-22 August, Copenhagen, Denmark, Paper ID 689.

[12] Andersen, R. V., Toftum, J., Andersen, K. K. and Olesen, B. W. (2009) 'Survey of occupant behaviour and control of indoor environment in Danish Dwellings', Energy and Buildings, 41: 1116.

[13] Knudsen, H. N., Valbjørn, O. and Nielsen, P. A. (1998) 'Determination of ExposureResponse Relationships for Emissions from Building Products', Indoor Air, 8: 264-275. [14] Wilkins, K., Wolkoff, P., Knudsen, H. N. and Clausen, P.A. (2007) 'The impact of information on perceived air quality - 'organic' vs. 'synthetic' building materials', Indoor Air, 17:130-134.

[15] Larsen, T. S., Knudsen, H. N. Kanstrup, A. M., Christiansen, E., Gram-Hanssen, K., Mosgaard, M., Brohus, H., Heiselberg, P. and Rose, J. (2010) Occupants influence on the energy consumption of Danish domestic buildings - State of the art, DCE Technical Report No 110, Aalborg University, Department for Civil Engineering, Section for Architectural Engineering. [16] Samson, R. A., Hockstra, E. S., Frisvad, J. C. and Filtenberg, O. (2002) Introduction to Foodand Airborne Fungi, Centraalbureau voor Schimmelcultures, Utrecht, Netherlands. 
[17] Roussel, S., Reboux, G., Bellanger, A-P, Sornin, S., Grenouillet, F., Dalphin, J-C, Piarroux, R and Millon, L. (2008) 'Characteristics of dwellings contaminated by moulds', Journal of Environmental Monitoring, 10: 724-729.

[18] Platts-Mills, T. A. E. and De Weck, A. L. (1989) 'Dust mite allergens and asthma - A worldwide problem', Journal of Allergy \& Clinical Immunology, 83: 416-427.

[19] Niven, R. McL., Fletcher, A. M., Pickering A. C., Custovic, A., Sivour, J. B., Preece, A. R., Oldham, L. A. and Francis, H. C. (1999) 'Attempting to control mite allergens with mechanical ventilation and dehumidification in British houses', Journal of Allergy Clinical Immunology, May 1999: 756-762.

[20] Arlian, L. G. and Veselica, M. M. (1981) 'Re-evaluation of the humidity requirements of the house dust-mites Dermatatophagoides farinae', Journal of Medical Entomology, 18: 351.

[21] Arlian, L. G. (1992) 'Water balance and humidity requirements of the house dust-mites', Experimental and Applied Acarology, 16: 15.

[22] Cunningham, M. J. (1998). 'Direct measurements of temperature and humidity in dust mite microhabitats, Clinical and Experimental Allergy, 28: 1104-1102.

[23] Appleby, A. (1990) 'Ch. C1 'Indoor Air Quality and Ventilation Requirements', in Buildings and Health, the Rosehaugh Guide to the Design, Construction, Use and Management of Buildings, RIBA Publications Ltd., London, UK, 176 in pp 167-193.

[24] Naydenov, K., Barankova, P., Sundell, J. and Melikov. A. (2004) ‘Distribution of Carbon Dioxide Produced by People in a Room: Part 2 - Field study', proc. 9th International Conference on Air Distribution in Rooms, ROOMVENT 2004, Coimbra, Portugal. ISBN 972-97973-2-3.

[25] Steiger, S., Hellwig, R. T. and Junker, E. (2008) 'Distribution of carbon dioxide in a naturally ventilated room with high internal heat load', in Proceedings of Indoor Air 2008, 11th International Conference on Indoor Air Quality and Climate, Aug. 17-22, Copenhagen, Denmark, paper 397.

[26] Anderson, B. R., Clark, A. J., Baldwin, R. and Milbank, N. O. (1985) BREDEM - BRE Domestic Energy Model: background, philosophy and description, BRE, Department of the Environment, Garston, UK. 
[27] SBSA (2007) 6.1 Carbon dioxide emissions and 6.2 Building insulation envelope, in Technical Handbooks 2007 (TH07), Scottish Building Standards Agency, Livingston, UK. [28] Kelly, N. J. K., Markopoulos,A. and Strachan, P. A. (2012) Environmental Assessment of Domestic Laundering: Final Modelling Report, Energy Systems Research Unit, Department of Mechanical and Aerospace Engineering, University of Strathclyde, www.homelaundrystudy.net [29] DEFRA (2011) 2011 Guidelines to Defra/DECC's GHG Conversion Factors for Company Reporting: Methodology Paper for Emission Factors, www.defra.gov.uk, pp14 \& 17.

[30] DEFRA (2008) Briefing Note BNW06: Assumptions underlying the energy projections for domestic tumble driers, Market Transformation Programme, first created 25/05/06, updated 13/08/07, last reviewed 18/01/08.

[31] Haas, D., Habib, J, Galler, H., Buzina, W., Schlacher, R., Marth, E, and Reinthaler, F. F. (2007) 'Assessment of indoor air in Austrian apartments with and without visible mold growth', Atmospheric Environment 41: 5192-5201.

[32] Viitanen, H. and Ojanen, T. (2007), Improved Model to Predict Mold Growth in Building Materials, proc. Thermal Performance of the Exterior Envelopes of Buildings X, proceedings of ASHRAE THERM X, Clearwater, Florida, USA, Dec. 2007, $5^{\text {th }}$ of 8 pages.

[33] Nevalainen, A. (1993) 'Microbial Contamination of Buildings', proc. Indoor Air '93, Helsinki, Finland, July 4-8, 4: 3-11.

[34] Garrett, M. H., Rayment, P. R., Hooper, M. A., Abramson. M. J., and Hooper, B. M. (1998) 'Indoor airborne fungal spores, house dampness and associations with environmental factors and respiratory health in children', Journal of Applied Bacteriology, 70: 61S-73S.

[35] Flannigan, B and Miller, J. D. (2001) Ch. 2.1 'Microbial Growth in Indoor Environments', in Microorganisms in Home and Indoor Work Environments, Eds. Brian Flannigan, Robert A. Samson and J. David Miller, CRC Press, Boca Raton, Florida, USA, 39.

[36] Park, J-H., Cox-Ganser, J. M., Kreiss, K., White, S. K. and Rao, C. Y. (2008), 'Hydrophilic Fungi and Ergosterol Associated with Respiratory Illness in a Water-Damaged Building', Environmental Health Perspectives, January, 116(1): 45-50. 
[37] Samson, R. A., Houbraken, J., Summerbell, R. C., Flanigan, B. and Miller, J. D. (2001) Ch. 5 'Common and important species of Actinomycetes and fungi in indoor environments', in Microorganisms in Home and Indoor Work Environments, Eds. Brian Flannigan, Robert A. Samson and J. David Miller, CRC Press, Boca Raton, Florida, USA, 340-345 in 287-473.

[38] Herbarth, O., Schlink, U., Müller, A and Richter, M. (2003) 'Spatiotemporal distribution of airborne mould spores in apartments', Mycological Research, 107(11): 1361-1371.

[39] Cunniffe, H. R. (2006) Environmental Determinants of Allergens in Different Flooring Materials and the Influence of Vacuum Cleaning on this and Airborne Allergen Concentrations, PhD Thesis, Coventry University (in collaboration with University of Worcester), UK. pp 66, 145$150,219-222,242-243,246-258,310$.

[40] Hung, L-L., Miller, J. D. and Dillon, H. K. (2005) Field Guide for the Determination of Biological Contaminants in Environmental Samples, American Industrial Hygiene Association. [41] ABF (2012) 'Water Damage in Building Materials', in Water Damage and Impact Studies in Florida, ABF Environmental Forensics, http://www.advbldg4.com/water-leak-damage.php [42] Andersen, B., Frisvad, J .C., Sondergaard, Ib., Rasmussen, Ib, S., and Larsen, L. S. (2011) 'Associations between Fungal Species and Water-Damaged Building Materials, Applied and Environmental Microbiology, June, Vol 77, No 12, 4180-4188.

[43] Thrasher, J. D. and Crawley, S. (2009), 'The biocontaminants and complexity of damp indoor spaces: more than what meets the eyes', Toxicology and Industrial Health, 25(9-10): 583-615. [44] ASHRAE (2005) Ch. 11 'Physiological Factors in Drying and Storing Farm Crops', in 2005 ASHRAE Handbook - Fundamentals (SI), ASHRAE, 11.2 in 11.1-11.18.

[45] WHO (2009) 2. 'Building dampness and its effect on indoor exposure to biological and nonbiological pollutants; 2.1 effects of dampness on the quality of the indoor environment', in WHO guidelines for indoor air quality: dampness and mould, World Health Organization, 12 in 9-13.

[46] Angell, W. J. and Olson, W. W. (1988) Moisture sources associated with potential damage in cold climate housing, CD-F0-3405-1988, Cold Climate Housing Information Center, University of Minnesota, St. Paul, MN, USA. 
[47] TenWolde, A. and Pilon, C. L. (2007) 'The Effect of Indoor Humidity on Water Vapor Release in Homes, in Proceedings of Buildings $X$ Conference, Dec. 2-7, Atlanta, Georgia, USA, ASHRAE, $1-9$

[48] Adan, O. C. G. (1994) On the fungal defacement of interior finishes, PhD Thesis, Eindhoven University, The Netherlands, 226 pages.

[49] Ginkel, J. T. V. and Hasselaar, E. (2005), Housing characteristics predicting mould growth in bathrooms, Proc. Indoor Air 2005, $10^{\text {th }}$ International Conference on Indoor Air, Sep. 4-9, Beijing, China, 2425-2429.

[50] Straube, J. F. and deGraauw, J. P. (2001), 'Indoor Air Quality and Hygroscopically Active Materials', ASHRAE Transactions, 107(Pt 1),: $8^{\text {th }}$ of 19 pages.

[51] Institute of Medicine (2000) ‘Executive Summary’ and Ch 5 'Indoor Biologic Exposures', in Clearing the Air, Asthma and Indoor Exposures, National Academic Press, Washington, DC, USA, pp5 in 1-18 \& 144,173 in 105-222.

[52] Cramer, R. A., Rivera, A. and Hohl, T. M. (2011), 'Immune responses against Aspergillus fumigatus: what have we learned?', Current Opinion in Infectious Diseases, 24, 315-322.

[53] Segal, B. H. (2009) 'Aspergillosis', New England Journal of Medicine, 360,:1870-1884.

[54] University of Cambridge (2011) 'Fungi and Lichens', Map of Life, www.map[oflife.org/browse/category_30 fungi-and -lichens/

[55] Beezhold, D.H., Green, B. J., Blachere, F. M., Schmechel, D., Weissman, D. N., Velickoff, D, Hogan, M. B. and Wilson, N. W. (2008) 'Prevalence of allergic sensitization to indoor fungi in West Virginia', Allergy and Asthma Proceedings, 29(1), Jan-Feb: 29-34.

[56] Esch, R. E. (2004) 'Manufacturing and standardizing fungal allergen products', Journal of Allergy and Clinical Immunology, 113: 210-215.

[57] Vijay, H., Burton, M., Young, N. M., Copeland, D. F. and Corlette, M. (1991) 'Allergenic components of isolates of Cladosporium herbarum', Grana, 30: 161-165.

[58] Perdomo, H., Sutton, D. A., Garcia, D., Fothergill, A. W., Cano, J., Gené, J., Summerbell, R. C., Rinaldi, M. G. and Guarro, J. (2011), 'Spectrum of Clinically Relevant Acremonium Species in the United States', Journal of Clinical Microbiology, 49(1): 243-256. 
[59] Kuhn, D. M. and Ghannoum, M. A. (2003) 'Indoor Mold, Toxigenic Fungi, and Stachybotrys chartarum: Infectious Disease Perspective', Clinical Microbiology Reviews, 16(1): 144-172.

[60] Nielsen, K. F. (2003) 'Mytoxin production by indoor molds', Fungal Genetics and Biology, 39: 103-117.

[61] Leino, M., Mäkelä, M., Reijula, K., Haatela, T., Mussalo-Rauhamaa, H., Tuomi, T., Hintikka, E. L. and Alenius, H. (2003) 'Intranasal exposure to a damp building Mould, Stachybotrys chartarum, induces lung inflammation in mice by satratoxin-independent mechanisms', Clinical and Experimental Allergy, 33(11): 1603-1610.

[62] Leino, M. (2006) Damp building moulds: Assessment of sensitization in patients and studies into mechanisms of airway inflammation using experimental models, PhD Thesis, University of Helsinki, Finland, 84 pages.

[63] Leino, M. S., Alenius, H. T., Fyhrquist-Vanni, N., Wolff, H. J., Reijula, K. E., Hintikka, E-L. Salkinoja-Salonen, M. S., Haatela, T. and Mäkelä, M. (2006) 'Intranasal Exposure to Stachybotrys chartarum Enhances Airway Inflammation in Allergic Mice', American Journal of Respiratory and Critical Care Medicine, 173(5): 512-518.

[64] Singh, J. (2005) 'Toxic Moulds and Indoor Air Quality', Indoor and Built Environment, 14(3-4): 229-234.

[65] Forgaes, J. and Carll, W. T. (1962) 'Mycotoxicosis', Advances in Veterinary Science, 7: 273293.

[66] Jarvis, B. B. (2002) 'Chemistry and toxicology of mould isolated from water damaged buildings', in Mytoxins and Food Safety, Eds. De Vries, J. W., Truckness, M. W., Jackson, L. S., Kluwer Academic, New York, USA, pp 42-52.

[67] Jarvis, B. B., Sorensen, W. G., Hintikka, E-L, Nikulin, M, Parkka, P., Etzel, R. A. and Dearborn, D. G. (1996) ‘Toxigenic Molds in Water-Damaged Buildings: Decholorogriseofulvins from Memnoniella echinata', Journal of Natural Products, 59(6): 553-554.

[68] Jürgensen, C. W. and Madsen, A. M. (2009) 'Exposure to the Airborne Mould Botrytis and its Health Effects', Annals of Agricultural and Environmental Medicine, 16: 183-196. 
[69] Niedoszytko, M., Chelminska, M., Jassem, E. and Czestochowska, E. (2007) 'Association between sensitization to Aureobasidium Pullulans (Pullularia sp) and severity of asthma', Annals of Allergy, Asthma \& Immunology, 98(February):153-156.

[70] Grant, C., Hunter, C. A., Flannigan, B. and Bravery, A. F. (1989) 'The moisture requirements of moulds isolated from domestic dwellings', International Biodeterioration and Biodegredation, 25: $259-284$.

[71] Nucci, M., Akiti, T., Barreiros, G, Silveira, F., Revankar, S. G., Sutton, D. A. and Patterson, D. F. (2001) 'Nosocomila Fungemia Due to Exophilia jeanselmei var. jeanselmei and a Rhinocladiella Species: Newly Described Causes of Bloodstream Infection', Journal of Clinical Microbiology, February, 39(2): 514-518.

[72] MBL (2005) 'The Mould Ucladium', Mold \& Bacteria Consulting Laboratories (MBL) Inc., Burnaby, BC, Canada, http://www.moldbacteriaconsulting.com/fungi/mould-ucladium.html, Aug. 3, 2005.

[73] Hope, R., Aldred, D. and Magan, N. (2005) 'Comparison of environmental profiles for grwth and deoxynivalenol production by Fusarium culmorum and F. graminearum on wheat grain', Letters in Applied Microbiology, 40(4): 295-300.

[74] Schwabe, M. and Krämer, A. (1995) 'Influence of water activity on the production of T-2 Toxin by Fusarium sporotrichioides', Myotoxin Research, March, 11(1): 48-52.

[75] Plaza, P., Usall, J., Teixidó, N. and Viñas, I (2003) ‘Effect of water activity and temperature on germination and growth of Penicilium digitatum, P. italicum and Geotrichum candidum', Journal of Applied Microbiology, 94(4) 549-554.

[76] Hameed, A. A. A., Yasser, I. H., and Khoder, I. M. (2004) 'Indoor air quality during renovation actions: a case study', Journal of Environmental Monitoring, 6: 740-744.

[77] Li, D-W. and Yang, C. S. (2004) 'Notes on indoor fungi 1:New records and noteworthy fungi from indoor environments', Mycotaxon, April-June, 89(2): 473-488.

[78] Prezant, B., Weekes, D. M. and Miller, J. D. (eds) (2008) Recognition, Evaluation and Control of Indoor Mold, American Industrial Hygiene Association, Fairfax, Virginia, USA. 
[79] Ministry of Social Affairs and Health (2003) Health Protection Act, Instructions regarding physical, chemical and biological factors in housing, Guidebook No 1, Finland (in Finnish).

[80] Reponen, T., Nevalainen, A., Jantunen, N, Pellikka, M. and Kalliokoski, P. (1992) 'Normal Range Criteria for Indoor Air Bacteria and Fungal Spores in a Subarctic Climate', Indoor Air, 2: 26-31.

[81] Kurup, V. P., Shen, H-D. and Banerjee, B. (2000) 'Respiratory fungal allergy', Microbes \& Infection, 2,: 1101-1110.

[82] Florian, M-L, Koestler, R. J., Nicholson, K., Parker, T. A., Stanley, T., Szczepanowska, H. and Wagner, S. (1994) Ch. 12 'Mold / Fungi, in Ninth Edition Paper Conservation Catalog, The Book and Paper Group of the American Institute for the Conservation of Historic and Artistic Works, Washington DC, USA, 4 in 1-39.

[83] Kilroy, C., Lagerstedt, A., Davey, A. and Robinson, K. (2006, revised 2007) 'Studies on the survivability of the invasive diatom Didymosphenia geminata under a range of environmental and chemical conditions', in NWA Client Report: CHC2006-116, National Institute of Water \& Atmospheric Research Ltd, Christchurch, New Zealand, 9, 11, 13 and 18 in 1-110.

[84] Richards, T. A. and Talbot, N. J. (2007) 'Plant Parasitic Oomycetes Such as Phytophthhora Species Contain Genes Derived from Three Eukaryotic Lineages', Plant Signaling \& Behavior, March-April, 2(2): 112-114.

[85] Porteous, C. D. A., Sharpe, T. R., Menon, R. Shearer, and D., Musa, with Baker, P. H., Sanders, C., Strachan, P. A., Kelly, N. J. and Markopoulos, A. (2012) Environmental Assessment of Domestic Laundering: Final Technical Report Project Module 1, Mackintosh Environmental Research Unit, The Glasgow School of Art, www.homelaundrystudy.net

[86] Arundel, A. V., Sterling, E. M., Biggin, J. H. and Sterling, T. D. (1986) 'Indirect Health Effects of Relative Humidity in Indoor Environments', Environmental Health Perspectives, 65: 351-361.

[87] Steinemann, A. C., Gallagher, L. G., Davis, A. L. and MacGregor, I. C. (2008) ‘Chemical Emissions from Residential Dryer Vents During Use of Fragranced Laundry Products', Air Quality, Atmosphere and Health, Vol. 1, No. 1, 1SSN 1873-9318. 
[88] Steinemann, A. C., MacGregor, I. C. Gordon, S. M., Gallagher, L. G., Davis, A. L., Ribeiro D. S. and Wallace, L. A. (2011) 'Fragranced Consumer Products: Chemicals emitted, ingredients unlisted', Environmental Impact Assessment Review, 3: 328-333.

[89] Caress, M S. and Steinemann, A. C. (2009) 'Prevalence of Fragrance Sensitivity in the American Population', Journal of Environmental Health, 71(7): 46-50.

[90] Menon, R., and Porteous, C. (2011) Design Guide: Healthy Low Energy Home Laundering, MEARU (Mackintosh Environmental Architecture Research Unit), The Glasgow School of Art, ISBN 978-0-9571595-0-1, www.homelaundrystudy.net

[91] DEFRA (2008) Briefing Note IBNW24: Innovation Briefing Note on domestic laundry drying products, Version 1.3, Market Transformation Programme, first created 07/02/07, updated 31/01/08, last reviewed 31/01/08.

[92] Porteous, C. and MacGregor, K. (2005) Ch 4 "Adaptive Control' and Ch 8 'Machine Control', in Solar Architecture in Cool Climates, Earthscan, London, UK, pp 91-118 and 184-191.

[93] Menon, R., Porteous, C. and Musa, H. (2010), Economic and Environmental Impact of Communal Laundry Spaces in High Density Housing in the UK, The International Journal of Environmental, Cultural, Economic and Social Sustainability, 6, ISSN 1832-2077 (12 p)

[94] Porteous, C. D. A. and Menon, R., (2010) Displacing Electrical Energy for Drying Domestic Laundry by Practical Solar Upgrades - Proposed Glasgow Housing Case Studies, Proceedings of EuroSun 2010, 28 September-1 October, Graz, Austria.

[95] Ventilation and Indoor Air Quality Task Group (2012) Mechanical Ventilation with Heat Recovery in New Homes, Interim Report January 2012, Zero Carbon Hub, NHBC Foundation, Milton Keynes, UK, 47 pages.

[96] Van der Pluijm, W. M. P. (2010) The Robustness and Effectiveness of Mechanical Ventilation in Airtight Dwellings, Master's Thesis, Eindhoven University of Technology, The Netherlands, [97] Vereeken, E., Roels, S. and Janssen, H. (2009) 'In situ determination of the moisture buffer potential of room enclosures', Journal of Building Physics, 34(3): 223-246.

[98] Janssen, H. and Roels, S. (2009) 'Qualitative and quantitative assessment of interior moisture buffering by enclosures', Energy and Buildings, 41: 382-394. 


\section{Endnotes:}

${ }^{1}$ The Mackintosh Environmental Architecture Research Unit (MEARU) within the Mackintosh School of Architecture, The Glasgow School of Art, conducted task (i) and led the project - EADL. Another research unit, Research into Indoor Climate and Health $(\mathrm{RICH})$, at Glasgow Caledonian University, covered task (ii). A third research unit, Energy Systems Research Unit (ESRU), University of Strathclyde, Glasgow, undertook work on task (iii) in liaison with RICH. MEARU is leading task (iv) as an ongoing component in association with RICH and ESRU.

${ }^{2}$ Table 3 of this document gives 334,351 GWh generated in 2009, with grid losses of $7.5 \%$ indicating a net value of 309,274.7 GWh; and when divided by the value in Table 7 for all energy used in generation by all methods in 2009 of 846,736 GWh gives a coefficient of 0.365 .

${ }^{3}$ Yeast was excluded from the list of isolates as it occurred in all case studies; and Fonsecaea pedrosoi was excluded as a human pathogen with no classification for water activity.

${ }^{4}$ A serious fire at the University of Strathclyde disrupted final work on objective 3 of EADL.

${ }^{5}$ Advanced Building Forensics Inc. classify Chaetomium spp. as tertiary with a water activity above 0.90; and Andersen et al state that it has 'concurrence and strong association' with other tertiary isolates such as Mucor Racemosus and Aspergillus fumigatus..

${ }^{6}$ Deemed to be mesophilic/secondary due to association with water-damage building materials.

${ }^{7}$ Deemed to be mesophilic/secondary after correspondence, 20/11/12, with Prof. Sidney Crowe, Georgia State University, who considered it analogous to Alternaria or Cladosporium.

${ }^{8}$ Deemed to be mesophilic/secondary, with $\mathrm{a}_{\mathrm{w}}$ range $0.87-0.91$ for four species of Fusarium.

${ }^{9}$ Advice to kill microorganisms such as dust mites in washing machines is commonly given as $60^{\circ} \mathrm{C}$, and $90^{\circ} \mathrm{C}$ for most bacteria, but those for fungal spores are more elusive. The Hygiene Council states: "Low temperature washes may not destroy all the germs and fungal spores." (www.hygienecouncil.org/Portals/1/pdf/Media_The_Truth_About_Germs_Fact_Sheet_pdf., 2012). 
The consumer advice of 'Which? Washing machine reviews: FAQs?' is that $60^{\circ} \mathrm{C}$ will remove mould spores as well as dust mites and bacteria (www.which.co.uk/home-and-garden/laundryand-cleaning/reviews/washing-machines/page/faqs/, 2012). Dr Nathan Yost of the Building Science Corporation, Somerville, MA, USA, claims: "Temperatures well above $100 \mathrm{~F}\left[38^{\circ} \mathrm{C}\right]$ will kill mold and mold spores, but the exact temperature to kill specific species is not well established." (www.realtor.org/realtororg.nsf/pages/moldfaq, 2012) Of the three citations, Florian et al state: "Most hydrated conidia and living hyphae are killed at temperatures just around $40^{\circ} \mathrm{C}$, .. , noting that the hypha is the 'unit of structure of most fungi', and a conidium a 'non-motile airborne asexual spore'. Work on a 'water mould' by Kilroy et al in New Zealand, which Richards and Talbot in the UK note has a genetic alignment ('gene transfer events') with fungi, also supports $40^{\circ} \mathrm{C}$ as a critical survival temperature in immersed conditions: "Exposure to $40^{\circ} \mathrm{C}$ was lethal to $D$. geminata after just 20 minutes" (section 2.4.2 Hot Water Treatment, $\mathrm{p} 18$; this also shown on Table 2, p13, with explanatory text). On the other hand, the same paper by Kilroy and her team finds that the survival extends to 1.2 days at $28^{\circ} \mathrm{C}$ (Table $\left.1, \mathrm{p} 11\right)$. 'Water moulds' are formally oomycetes, a group within heterokants, a major group of algae, including Didyomosphenia geminata. In summary, although work of this nature is relatively limited, it does align with informal consumer advice and adds authority to the proposition that low-temperature washes may have exacerbated the incidence of CFUs associated with PID. 
TABLE 1 Spot data averages for 100 dwellings

\begin{tabular}{|c|c|c|c|c|c|c|}
\hline Room & $\mathrm{CO}_{2}(\mathrm{ppm})$ & $\%>1,000 p p m$ & Temp. $\left({ }^{\circ} \mathrm{C}\right)$ & $\mathrm{RH}(\%)$ & $\mathrm{VP}(\mathrm{kPa})$ & $\%>1.13 \mathrm{kPa}$ \\
\hline Living Rm & 1,248 & $25 \%(24 \%<)$ & 19.6 & 51.5 & 1.16 & $3 \%$ \\
\hline Bedroom 1 & 1,314 & $31 \%(21 \%<)$ & 19.1 & 52.4 & 1.15 & $2 \%$ \\
\hline Bedroom 2 & 1,192 & $19 \%(31 \%<)$ & 19.3 & 56.2 & 1.24 & $10 \%$ \\
\hline Kitchen & 1,245 & $25 \%(26 \%<)$ & 19.2 & 52.5 & 1.16 & $3 \%$ \\
\hline Bathroom & 1,297 & $30 \%(21 \%<)$ & 18.3 & 56.8 & 1.17 & $4 \%$ \\
\hline Hall & 1,314 & $31 \%(20 \%<)$ & 18.9 & 53.3 & 1.15 & $2 \%$ \\
\hline
\end{tabular}

Note: the $3^{\text {rd }}$ column values in parenthesis (e.g. $(24 \%<)$ for living room) indicate percentage of dwellings where the $\mathrm{CO}_{2}$ spot values were below $1,000 \mathrm{ppm}$. In other words, the remaining $76 \%$ of living rooms will be more than $25 \%$ above $1,000 \mathrm{ppm}$ - in fact averaging $1,355 \mathrm{ppm}$ or $36 \%$ above the accepted maximum level in this instance. 
TABLE 2: Air Quality and Moisture - numerical means

CS Season CFU M AQ-L AQ-B VP-L VP-B RH-L RH-B RH-K mean mean mean mean mean mean mean mean $\begin{array}{llllllll}/ \mathrm{m}^{3} & \mathrm{ppm} & \mathrm{ppm} & \mathrm{kPa} & \mathrm{kPa} & \% & \% & \%\end{array}$

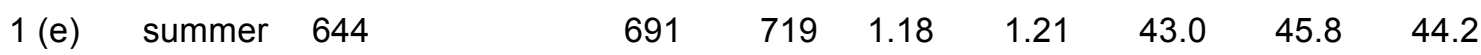

$\begin{array}{lllllllllll}2(\mathrm{~g}) & \text { winter } & 914 & \mathrm{~B} & 932 & 991 & 0.94 & 1.13 & 39.0 & 45.5 & 48.1\end{array}$

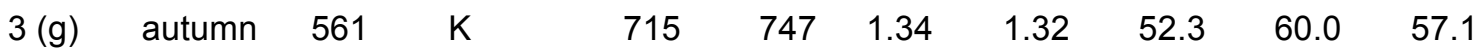

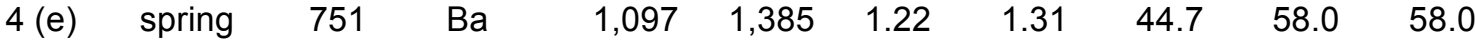

$\begin{array}{lllllllllll}5(\mathrm{e}) & \text { autumn } & 466 & \mathrm{~B} & 833 & 2,232 & 1.27 & 1.47 & 62.5 & 61.4 & 59.6\end{array}$

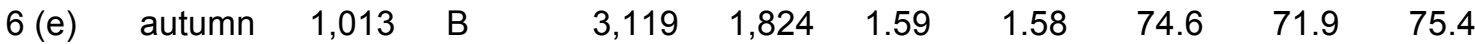

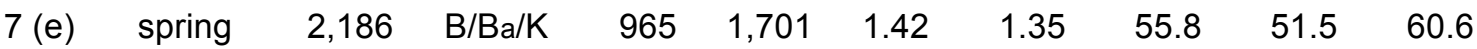

$\begin{array}{lllllllllll}8(\mathrm{~g}) & \text { autumn } & 587 & \mathrm{~K} & 836 & 1,134 & 1.35 & 1.40 & 61.3 & 75.8 & 71.2\end{array}$

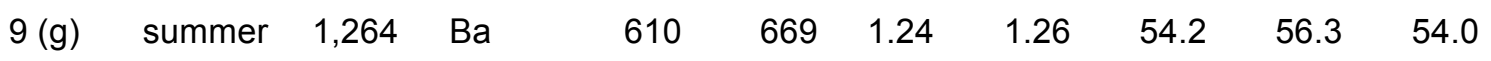

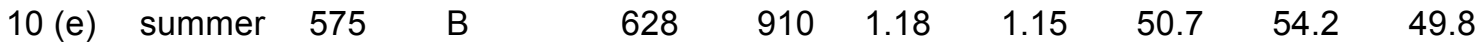

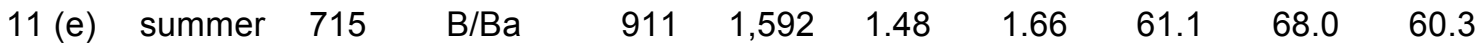

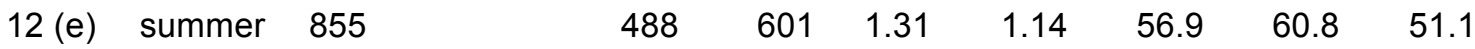

$\begin{array}{llllllllll}13(\mathrm{e}) & \text { summer } & 526 & 972 & 850 & 1.27 & 1.25 & 47.7 & 45.0 & 48.0\end{array}$

$\begin{array}{llllllllll}14(\mathrm{~g}) & \text { summer } & 687 & 709 & 699 & 1.17 & 1.19 & 56.9 & 53.1 & 48.6\end{array}$

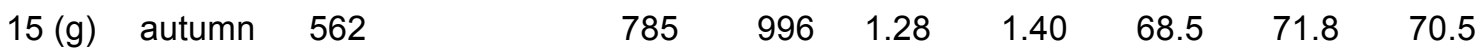

16 (g) spring $\quad 685 \quad \mathrm{~B} / \mathrm{Ba} \quad 1,478$ no d. $1.26 \quad$ no d. $47.3 \quad$ no d. 48.7

$\begin{array}{llllllllll}17(\mathrm{e}) & \text { spring } & 752 & 531 & 828 & 0.92 & 1.01 & 33.9 & 56.9 & 40.3\end{array}$

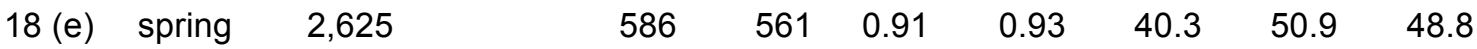

$\begin{array}{llllllllll}19(\mathrm{e}) & \text { spring } & 1,259 & 906 & 767 & 1.09 & 1.10 & 44.4 & 53.2 & 51.6\end{array}$

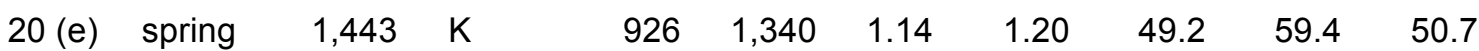

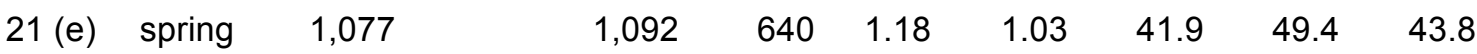




\section{Table 2 Legend:}

CS = Case Study number, the sequence 1-22 of analysis of the 22 volunteers from the 100 households initially surveyed. This order was adopted to facilitate a coherent line of narrative research enquiry, and it is out of chronological sequence relative to the surveys. Electric (e) and gas $(\mathrm{g})$ heating in parenthesis after CS number.

CFU mean $/ \mathrm{m}^{3}=$ mean number of 'colony forming units' found in each of 5-6 spaces by MEA (malt extract sugar) given in table; PDA (potato dextrose agar) also used; noting that the mean maxima for PDA was $1.265 \%$ higher than for MEA, and the overall mean average of 849 is $1.31 \%$ more than that found by PDA (838). Note also that a limiting value of $500 \mathrm{CFU} / \mathrm{m}^{3}$ is used in Finland for indoor air in urban areas in winter (Ministry of Social Affairs and Health, 2003 (Finland); cited in 'WHO guidelines for indoor air quality: dampness and mould', 2009).

$A Q-L / A Q-B$ mean ppm $=$ mean $\mathrm{CO}_{2}$ in living room and bedroom(s); noting that $5,000 \mathrm{ppm}$ is the maximum instrument value; and where two bedrooms, highest value used.

VP-L/VP-B mean $\mathrm{kPa}=$ mean vapour pressure in living room and bedroom(s).

$\mathrm{RH}-\mathrm{L} / \mathrm{RH}-\mathrm{B} / \mathrm{RH}-\mathrm{K}$ mean $\%$ = mean $\mathrm{RH} \%$ in living room, bedroom(s) \& kitchen. 
TABLE 3: Air Quality and Moisture - qualitative relativities

\begin{tabular}{|c|c|c|c|c|c|c|c|c|c|c|}
\hline CS & Season & TD & OD & ID & CFU & $M$ & AQ-L & $A Q-B$ & VP-L & VP-B \\
\hline 1 (e) & summer & $\checkmark$ & & & I-mod. & & good & good & high & high \\
\hline 2 (g) & winter & & & $\checkmark$ & h-mod. & B & mod. & poor & high & high \\
\hline $3(\mathrm{~g})$ & autumn & $v v$ & & $\checkmark$ & I-mod. & $\mathrm{K}$ & good & mod. & high & high \\
\hline $4(e)$ & spring & $\checkmark$ & $\checkmark$ & $\checkmark$ & mod. & $\mathrm{Ba}$ & poor & poor & high & high. \\
\hline $5(e)$ & autumn & $\checkmark$ & & & low & B & mod. & poor & high & high \\
\hline $6(\mathrm{e})$ & autumn & $\checkmark$ & & & high & B & poor & poor & high & high \\
\hline $7(\mathrm{e})$ & spring & & & $\checkmark$ & high & $\mathrm{B} / \mathrm{Ba} / \mathrm{K}$ & poor & poor & high & high \\
\hline $8(\mathrm{~g})$ & autumn & $v \checkmark$ & & $\checkmark$ & I-mod. & $\mathrm{K}$ & good & poor & high & high \\
\hline $9(\mathrm{~g})$ & summer & & & $\checkmark$ & high & $\mathrm{Ba}$ & good & good & high & high \\
\hline $10(e)$ & summer & $v \checkmark$ & & $\checkmark$ & I-mod. & B & good & mod. & mod. & mod. \\
\hline $11(\mathrm{e})$ & summer & $\checkmark v$ & & $\checkmark$ & h-mod. & $\mathrm{B} / \mathrm{Ba}$ & good & poor & high & high \\
\hline $12(\mathrm{e})$ & summer & $\checkmark$ & & $\checkmark$ & h-mod. & & good & good & mod. & mod. \\
\hline $13(e)$ & summer & $\checkmark$ & & & I-mod. & & good & good & high & high \\
\hline $14(g)$ & summer & & & $\checkmark$ & h-mod. & & mod. & good & mod. & mod \\
\hline $15(g)$ & autumn & & $v V$ & $\checkmark$ & I-mod. & & good & good & high & high \\
\hline $16(g)$ & spring & & $\checkmark$ & & I-mod. & $\mathrm{B} / \mathrm{Ba}$ & poor & no d. & high & no d. \\
\hline $17(\mathrm{e})$ & spring & & $\checkmark v$ & $v$ & h-mod. & & good & good & mod. & $\bmod$ \\
\hline $18(\mathrm{e})$ & spring & & & $\checkmark$ & high & & good & good & low & $\bmod$ \\
\hline 19 (e) & spring & & & $v$ & high & & mod. & mod. & mod. & high \\
\hline $20(e)$ & spring & & & $\checkmark$ & high & $\mathrm{K}$ & poor & poor & high & high \\
\hline $21(\mathrm{e})$ & spring & & & $v$ & high & & poor & good & high & $\bmod$ \\
\hline 22 (g) & winter & & & $\checkmark$ & high & & poor & poor & high & low \\
\hline
\end{tabular}




\section{Table 3 Legend:}

e/g = electric or gas heating (fixed appliances mainly storage in case of electric heating)

TD = tumble drier, including where in laundrette or other communal facility; where double-ticked indicates the dominant strategy where there more than one drying technique is used.

$\mathrm{OD}=$ outside drying, whether using communal or private space.

$I D=$ internal drying within the home, frequently employing more than one room or space.

$\mathrm{CFU}=$ colony forming unit (mould spores), expressed per $\mathrm{m}^{3}$ from analysis of air samples; where high $=>1,000$, h-mod/ I-mod. (high/low-moderate) 700-1,000/500-700, low $<500$.

$M=$ mould - its visible presence at time of survey; B: bedroom, Ba: bathroom, K: kitchen.

$A Q-L / A Q-B=$ air quality in living room and bedrooms; where good $=C_{2}$ mean $>1,000$ and max . $<2,000$ ppm; mod. $=$ mean $<1,000$, max. $>2,000 ;$ poor $=$ mean $>1,000$, max. $>2,000$.

VP-L/VP-B = vapour pressure in living room and bedrooms; where high $=\max .>1.6 \mathrm{kPa}$; mod. $=$ mean $<1.2 \mathrm{kPa}$, but max. $>1.3 \mathrm{kPa}$; low $=\max <1.2 \mathrm{kPa}$; noting $1.13 \mathrm{kPa}$ or $7 \mathrm{~g} / \mathrm{kg}$ mixing ratio is dust mite threshold (Platts-Mills \& De Weck,1989; Niven et al, 1999), and $1.6 \mathrm{kPa}$ or circa 10 $\mathrm{g} / \mathrm{kg}$ gives $\mathrm{RH}$ levels above $70 \%$ for temperatures $<19.7^{\circ} \mathrm{C}$.

no $d .=$ no data available, in relation to $A Q$ and VP above. 
TABLE 4: means and standard deviations

CFU_all spaces (arithmetic mean)

\begin{tabular}{|l|r|r|c|}
\hline Ind. Var. & Mean & $\mathrm{N}$ & Std. Deviation \\
\hline IV1TD & 644.63 & 8 & 149.002 \\
IV2:POD & 681.67 & 3 & 70.002 \\
IV3:PID & 1388.33 & 9 & 604.369 \\
IV4:mix & 808.00 & 2 & 66.468 \\
Total & 968.77 & 22 & 526.243 \\
\hline
\end{tabular}


TABLE 5: means and standard deviations

CFU_living/bedrooms (arithmetic mean)

\begin{tabular}{|l|r|r|c|}
\hline Ind. Var. & Mean & $\mathrm{N}$ & Std. Deviation \\
\hline IV1:TD & 661.88 & 8 & 181.681 \\
IV2:POD & 688.33 & 3 & 120.010 \\
IV3:PID & 1528.33 & 9 & 716.378 \\
IV4:mix & 838.50 & 2 & 55.861 \\
Total & 1036.00 & 22 & 621.460 \\
\hline
\end{tabular}


Table 6: $\mathrm{F}$ tests comparing drying methods

\begin{tabular}{|c|c|c|c|c|c|c|}
\hline & & Sum of Squares & df & Mean Square & $\mathrm{F}$ & Sig. \\
\hline Cfu_all & $\begin{array}{l}\text { Between Groups } \\
\text { Within Groups } \\
\text { Total }\end{array}$ & $\begin{array}{l}2723839.322 \\
3091724.542 \\
5815563.864\end{array}$ & $\begin{array}{l}3 \\
18 \\
21\end{array}$ & $\begin{array}{l}907946.441 \\
171762.475\end{array}$ & 5.286 & .009 \\
\hline Cfu_liv/bed & $\begin{array}{l}\text { Between Groups } \\
\text { Within Groups } \\
\text { Total }\end{array}$ & $\begin{array}{l}3741913.958 \\
4368550.042 \\
8110464.000\end{array}$ & $\begin{array}{l}3 \\
18 \\
21\end{array}$ & $\begin{array}{c}1247304.653 \\
242697.225\end{array}$ & 5.139 & .010 \\
\hline
\end{tabular}


Table 7: means and the t-test for former IV1, $2 \& 4$ as 0 and IV3 as 1.00

\begin{tabular}{|rc|c|c|c|c|}
\hline & IV3 & N & Mean & Std. Deviation & Std. Error Mean \\
\hline CFU_all & .00 & 13 & 678.31 & 133.035 & 36.897 \\
& 1.00 & 9 & 1388.33 & 604.369 & 201.456 \\
\hline
\end{tabular}




\begin{tabular}{|c|c|c|c|c|c|c|c|}
\hline \multirow[b]{3}{*}{ CFU_all } & \multicolumn{7}{|c|}{ Table 8: t-test for Equality of Means } \\
\hline & \multirow[b]{2}{*}{$\mathrm{t}$} & \multirow[b]{2}{*}{$\mathrm{df}$} & \multirow[b]{2}{*}{$\begin{array}{c}\text { Sig. } \\
\text { (2-tailed) }\end{array}$} & \multirow[b]{2}{*}{$\begin{array}{c}\text { Mean } \\
\text { Difference }\end{array}$} & \multirow[b]{2}{*}{$\begin{array}{l}\text { Std. Error } \\
\text { Difference }\end{array}$} & \multicolumn{2}{|c|}{$\begin{array}{c}\text { 95\% Confidence } \\
\text { Interval of Difference }\end{array}$} \\
\hline & & & & & & Lower & Upper \\
\hline Equal variances assumed & -4.136 & 20 & .001 & -710.026 & 171.667 & -1068.116 & -351.935 \\
\hline Equal variances not assumed & -3.467 & 8.539 & .008 & -710.026 & 204.807 & -1177.170 & -242.881 \\
\hline
\end{tabular}


Table 9: Multiple regression of 7 potential confounding variables

\begin{tabular}{|c|c|c|c|c|c|}
\hline \multirow[b]{2}{*}{ Model: CFU-all } & \multicolumn{2}{|c|}{ Unstandardized Coefficients } & \multirow{2}{*}{$\begin{array}{l}\text { Standardized } \\
\text { Coefficients } \\
\text { Beta }\end{array}$} & \multirow[b]{2}{*}{$\mathrm{T}$} & \multirow[b]{2}{*}{ Sig. } \\
\hline & B & Std. Error & & & \\
\hline (Constant) & 524.483 & 262.355 & & 1.999 & .067 \\
\hline IV3:PID & 682.856 & 182.845 & .653 & 3.735 & .002 \\
\hline spring & 307.786 & 212.910 & .288 & 1.446 & .172 \\
\hline Floor Cover & 127.343 & 179.971 & .122 & .708 & .492 \\
\hline Plants & 154.671 & 189.903 & .140 & .814 & .430 \\
\hline Heat & -184.802 & 181.198 & -.177 & -1.020 & .326 \\
\hline Fan_kit & 318.247 & 174.626 & .308 & 1.822 & .091 \\
\hline Fan_bath & -110.047 & 200.079 & -.100 & -.550 & .592 \\
\hline Window open & -54.761 & 200.867 & -.045 & -.273 & .789 \\
\hline
\end{tabular}


TABLE 10 Comparative presence of isolate types in cases above and below $1,000 \mathrm{CFU} / \mathrm{m}^{3}$

\begin{tabular}{|c|c|c|c|c|c|c|}
\hline Case study & Case study & $\mathrm{CFU} / \mathrm{m}^{3}$ & Tertiary: out & All: out of 49 & Secondary: out & Notes \\
\hline$>1000 / \mathrm{m}^{3}$ & $<1000 / \mathrm{m}^{3}$ & & of 19 No. (\%) & No. (\%) & of 16 No. (\%) & \\
\hline CS7 & & 2,110 & $7(37)$ & $15(31)$ & $5(31)$ & Set of 6 PID cases \\
\hline CS9 & & 1,251 & $7(37)$ & $22(45)$ & $7(44)$ & with more than \\
\hline CS18 & & 2,625 & $5(26)$ & $16(33)$ & $7(44)$ & $1,000 \mathrm{CFU} / \mathrm{m}^{3}$ \\
\hline CS19 & & 1,279 & $6(32)$ & $15(31)$ & $5(31)$ & $\begin{array}{l}\text { greater proportion } \\
\text { of specific tertiary }\end{array}$ \\
\hline CS20 & & 1,317 & $4(21)$ & $17(35)$ & $7(44)$ & isolates - see \\
\hline \multirow[t]{17}{*}{ CS21 } & & 1,111 & $10(53)$ & $20(41)$ & $5(31)$ & Table 11 \\
\hline & Means & 1,616 & $6.5(34)$ & $17.5(36)$ & $6.0(38)$ & \\
\hline & CS1 & 902 & $3(16)$ & $16(33)$ & $8(50)$ & Set of 14 non-PID \\
\hline & CS3 & 560 & $5(26)$ & $16(33)$ & $7(44)$ & dominated cases \\
\hline & CS4 & 755 & $5(26)$ & $17(35)$ & $7(44)$ & with less than \\
\hline & CS5 & 565 & $5(26)$ & $14(29)$ & $5(31)$ & $\begin{array}{l}\text { 1,000 CFU/m³ } \\
\text { lesser proportion }\end{array}$ \\
\hline & CS6 & 990 & $3(16)$ & $15(31)$ & $6(38)$ & of specific tertiary \\
\hline & CS8 & 594 & $4(21)$ & $15(31)$ & $5(31)$ & isolates - see \\
\hline & CS10 & 587 & $7(37)$ & $18(37)$ & $6(38)$ & Table 11 \\
\hline & CS11 & 696 & $4(21)$ & $14(29)$ & $5(31)$ & \\
\hline & CS12 & 855 & $4(21)$ & $12(24)$ & $5(31)$ & \\
\hline & CS13 & 526 & $5(26)$ & $11(22)$ & $2(16)$ & \\
\hline & CS14 & 687 & $6(32)$ & $19(39)$ & $8(50)$ & \\
\hline & CS15 & 612 & $2(11)$ & $12(24)$ & $6(38)$ & \\
\hline & CS16 & 681 & $7(37)$ & $20(41)$ & $8(50)$ & \\
\hline & CS17 & 752 & $8(42)$ & $20(41)$ & $7(44)$ & \\
\hline & Means & 697 & $4.9(26)$ & $15.6(32)$ & $6.1(38)$ & \\
\hline
\end{tabular}


Note: Total 49 isolates (49 No.) identified, of which 19 are tertiary, 14 are secondary and the balance of which are primary; yeast isolate ignored as present in all case studies. 
TABLE 11 Proportions of specific tertiary isolates: sets above* $\&$ below ${ }^{* *} 1,000 \mathrm{CFU} / \mathrm{m}^{3}$

\begin{tabular}{|c|c|c|c|c|c|c|}
\hline Acremonium & Botrytis & Chaetomium & Memnoniella & Phoma & Rhizopus & Stachybotrys \\
\hline strictum & cinerea & spp. & echinata & herbarum & stolinifer & chartarum \\
\hline No. (\%) & No. (\%) & No. (\%) & No. $(\%)$ & No. (\%) & No. (\%) & No. (\%) \\
\hline $2(33)$ & $3(50)$ & $3(50)$ & $2(33)$ & $4(67)$ & $5(83)$ & $2(33)$ \\
\hline $2(14)$ & $3(21)$ & $3(21)$ & $0(0)$ & $6(43)$ & $6(43)$ & $1(7)$ \\
\hline
\end{tabular}

Note: Proportions given in number (No.) and percentage of specific isolates identified in set of six PID cases* above $1,000 \mathrm{CFU} / \mathrm{m}^{3}$ (1st row of values); and in set of fourteen cases that are not PID-dominated ${ }^{* *}$ below $1000 \mathrm{CFU} / \mathrm{m}^{3}$ (2 ${ }^{\text {nd }}$ row of values). For example, column 1 of the 1 st row means 2 No. or $33 \%$ of a set of six PID cases; and column 1 of the 2 nd row means 2 No. or $14 \%$ of a set of fourteen non-PID. 


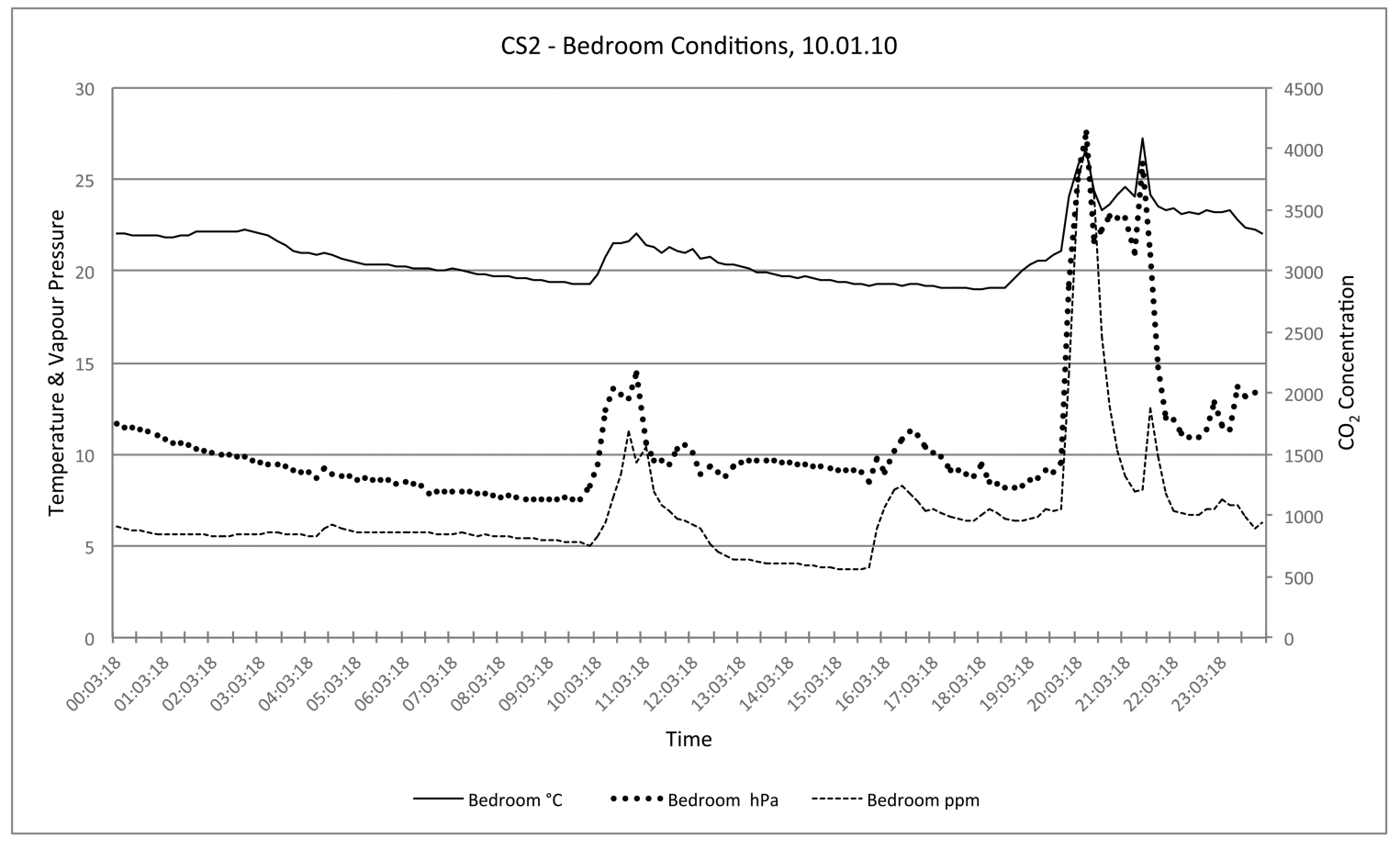

Fig. 1 Typical moisture and $\mathrm{CO}_{2}$ relativity in a bedroom, also used for passive indoor drying. 


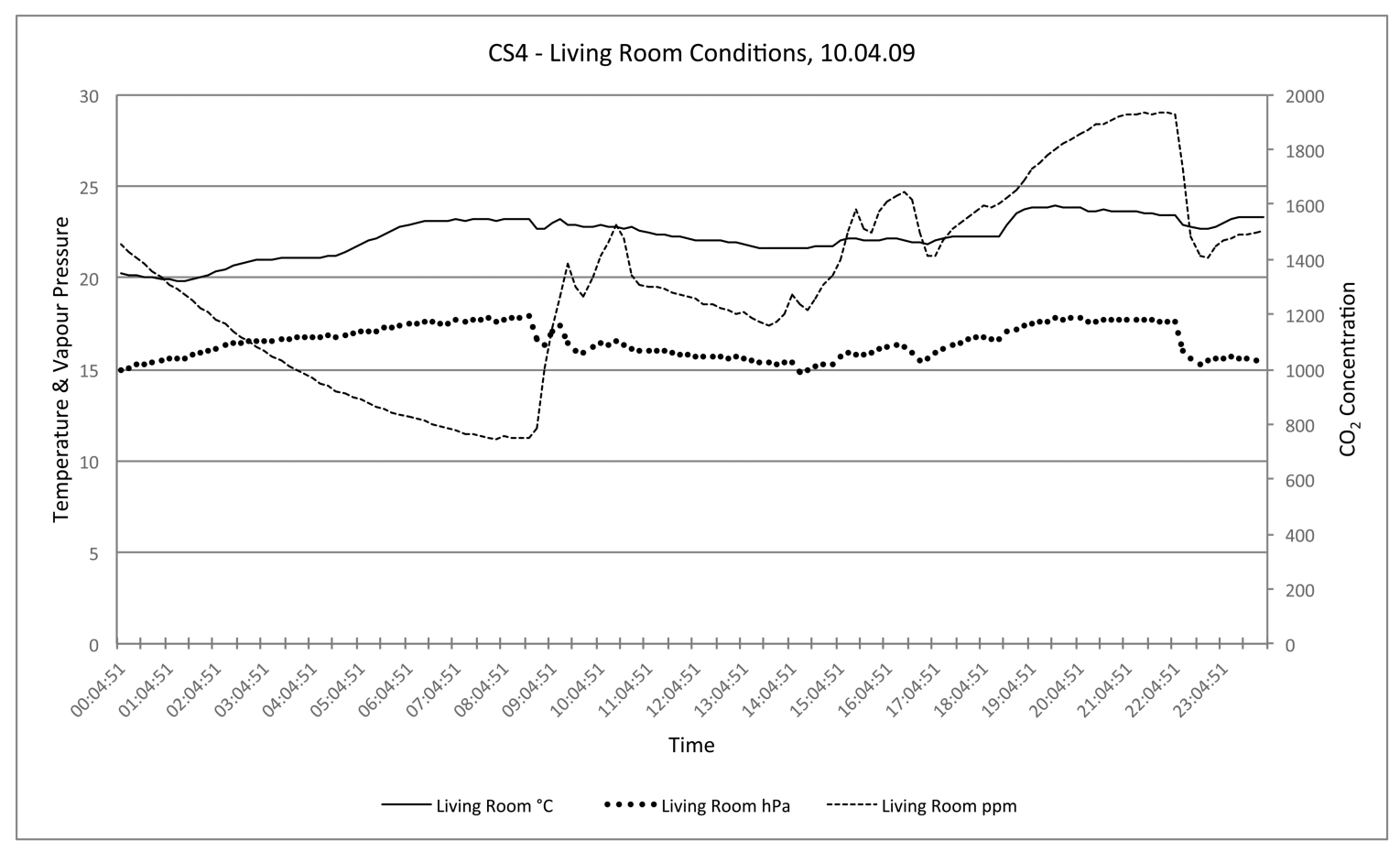

Fig. 2 Overnight drying juxtaposition of moisture and $\mathrm{CO}_{2}$ compared with evening occupancy 


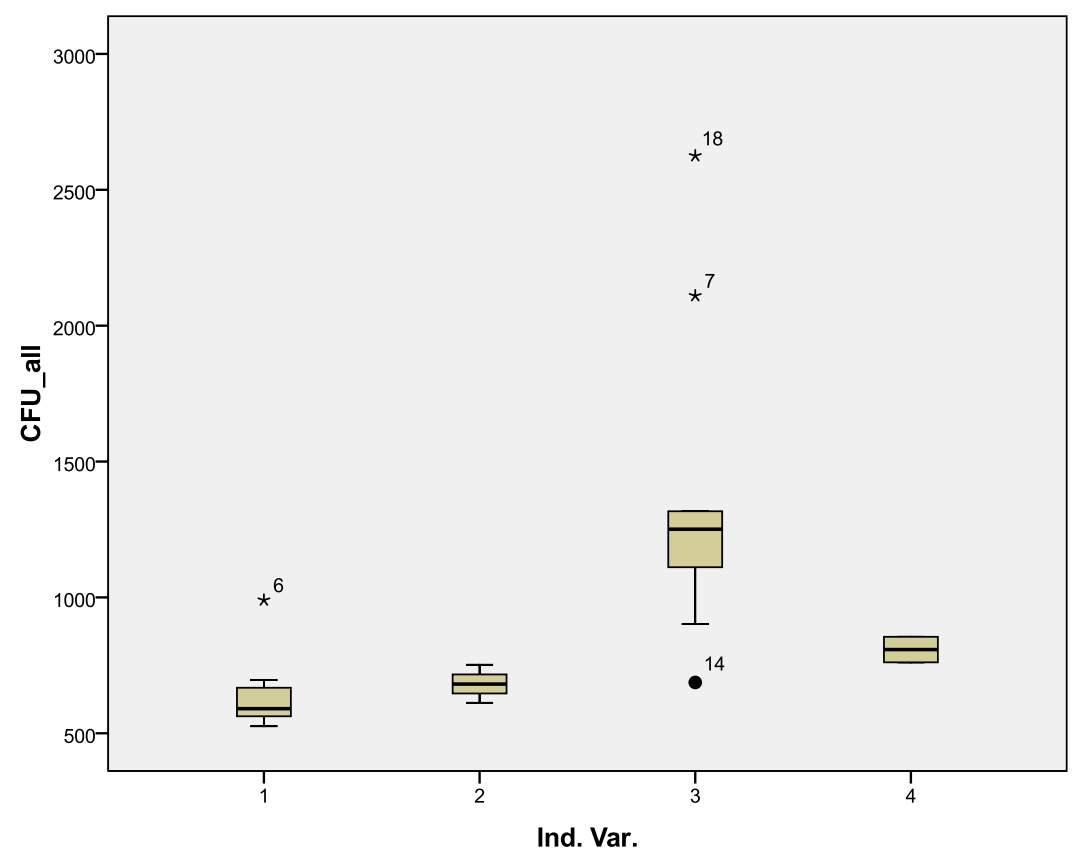

Fig. 3 Boxplot

Note: box is the interquartile range, heavy line the median; case numbers of outliers are shown.

[File: MEARU_EPSRC_paper_0513p1v9

CP 27/05/13] 